\title{
STRAH I ODLUKE O ZDRAVLJU DJECE
}

Izvorni znanstveni članak

Primljeno: 1. 4. 2019

Prihvaćeno: 3. 5. 2019

DOI: $10.15176 /$ vol56no105

UDK 351.774.7:613.95

27-423.42

\author{
IVANA KATARINČIĆ \\ Institut za etnologiju i folkloristiku, Zagreb
}

\begin{abstract}
Aktualna tema u hrvatskoj javnosti već je dulje vrijeme propitivanje (obaveznog) procjepljivanja djece. Informacije o nužnosti i (ne)opravdanosti cijepljenja djece plasirane su u javnost različitim kanalima iz oprečnih okulara, često samo fragmentarno, što za posljedicu ima to da su ideje o cijepljenju u znatnoj mjeri obavijene različitim predrasudama i pretpostavkama, ali i polarizaciju neistomišljenika. Oprečna mišljenja i stavovi generirali su suprotstavljene pozicije onih koji obavezu cijepljenja zagovaraju i onih koji se toj obavezi opiru. Pritom se i jedna i druga strana iz različitih razloga osjećaju ugroženo i zastrašeno te im je objema zajednički strah (bilo od posljedica cijepljenja ili posljedica necijepljenja) te briga za zdravlje djece. Analiza je usmjerena na predodžbe, strahove i prijeporne točke artikulirane $u$ javnom prostoru te produkciju i percepciju (ne)formalnih znanja. U središtu pozornosti je heterogena skupina kritičara cijepljenja koja, osim što uznemiruje dominantni diskurs, akumulira različite strahove koji su posljedica sumnji, nepovjerenja, (ne)informiranosti. Ukazivanjem na vrlo konkretne probleme i propuste $u$ sustavu cijepljenja, ta skupina dovodi u pitanje obavezu na preventivni postupak. lako se nadležnost odlučivanja i raspravljanja o cijepljenju dodjeljuje prvenstveno medicinskom i tek dijelom pravnom području, tema se propituje i iz drugih očišta, posebno njezini etički, politički i ideološki aspekti s obzirom na to da ideja kontroverzne medicinske intervencije zadire u odluke o zdravlju i bolestima djece koje uključuju ljudska prava, slobode i odgovornosti.
\end{abstract}

Ključne riječi: strah, cijepljenje, rizik, djeca, zdravlje

Prijeporna, važna i u hrvatskoj javnosti već duže vrijeme aktualna tema, politika je procjepljivanja djece. Informacije o nužnosti i (ne)opravdanosti cijepljenja djece komuniciraju se u javnosti različitim kanalima, iz oprečnih okulara, a informacije su često, u skladu s prirodom medija u kojima nastaju i kojima se šire (web portali, društvene mreže, tv emisije i sl.), površne i selektivne. $U$ raspravama je rijetko omogućen istinski dijalog. $U$ njima izostaje ulazak u meritum stvari te se često svode na rasprave o uvjerenjima, vjerovanjima i na druga ideološka pitanja. Čak i kada su u javne rasprave uključeni stručnjaci (bilo medicinske ili neke druge struke) one često zrcale različita uvjerenja, suprotstavljena (više 
ili manje oficijelna) znanja, (ne)priznata iskustva, pojedinačne strahove, strahove određenih afektivnih zajednica i sl. Spomenuta medijska slika naizgled je generirala (samo) dvije suprotstavljene pozicije te je zamjetno $u$ javnom diskursu da se rasprave vrlo često svode na pitanje je li cijepljenje nužno ili nije. Međutim, provedenim je istraživanjem utvrđeno da rasprave o cijepljenju nisu svodive na da ili ne opciju, a temeljnim problemom politike masovnog i neindividualiziranog procjepljivanja pokazala se zakonska obaveza.

Otkriva se stoga u kakvom su odnosu (državni i međunarodni) zakonski okviri koji, osim obaveze cijepljenja, reguliraju sigurne postupke pri medicinskim intervencijama te prava i slobode pacijenata. Uspoređene su preporučene dobre prakse u medicinskim postupcima i upozorenja proizvođača cjepiva s pojedinim iskustvima u praksi te pojedina strahovanja i percepcije polariziranih grupacija.

Kako bih jasnije objasnila stvorene pozicije i neuralgične točke koje one proizvode, $u$ tekstu će biti dan glas prvenstveno kritičarima cijepljenja (bez obzira na to kritiziraju li samo obavezu ili i ideju cijepljenja) te u manjem obimu zagovornicima cijepljenja (bez obzira na to smatraju li obavezu opravdanom ili ne). Razlog neravnomjerne zastupljenosti u usmjerenosti je istraživanja na prepoznavanje uzroka zabrinutosti i straha najčešće onih koji više ili manje jasno i koncizno artikuliraju kritiku politike cijepljenja. Napominjem da moje akademske kompetencije ne uključuju medicinska znanja te ću raspravu usmjeriti na predodžbe, strahove i prijepore artikulirane u intervjuima s mojim sugovornicima i one prisutne među korisnicima društvenih mreža. Znanja i stavovi medicinskih stručnjaka kao i medicinske činjenice korišteni su u svrhu ilustracije društvenih, kulturnih, ekonomskih ili nekih drugih aspekata problematike koja se istražuje. ${ }^{2}$

Osim brige za zdravlje djece, zajednički objema stranama često je strah. Strah je konstanta koja natkriljuje suprotstavljene pozicije premda su dionici rasprave na različitim pozicijama moći (npr. odnos liječnik - roditelj). Neki od dominantnih strahova su: strah od pojavljivanja novih epidemija i vraćanja starih zaraznih bolesti, strah od moćnih farmaceutskih lobija, strah od nepovjerenja u znanost, strah od urušavanja ostataka javnog zdravstva, strah od kontrole, strah od neželjenih posljedica cijepljenja, strah od (ne)odgovornosti (prema djeci, društvu), strah od ismijavanja, strah od uskraćivanja informacija, strah od sankcija, strah od neodgovornosti ili čak malicioznosti sustava javnog zdravstva,

\footnotetext{
${ }^{1}$ Pritom, postoje inicijative koje predlažu pravo izbora, a ne izostavljanje ili, kako se još u medijima i javnom diskursu provlači, zabranjivanje ili uskraćivanje cijepljenja.

${ }^{2}$ Informacije na kojima se temelji ovaj rad, osim u stručno-znanstvenoj literaturi, prikupljala sam klasičnom metodom (formalnog i neformalnog) etnološkog i antropološkog intervjuiranja, a koristila sam i informacije u obliku komentara i rasprava dostupnih u javnim medijima i društvenim mrežama. Također, mnoge korisne informacije prikupljene su na službenim stranicama HALMED-a, Agencije za lijekove i medicinske proizvode (http://www.halmed.hr/), CDC-a, Centra za prevenciju i kontrolu bolesti (Centers for Disease Control and Prevention) (https://www.cdc.gov/), stranicama građanske inicijative Cijepljenje - pravo izbora Cijepljenje. info (http://cijepljenje.info/) te stranicama facebook grupe Cijepljenje/Vakcinacija - grupa za sve koji imaju pitanja i nedoumice (https://www.facebook.com/groups/459227237920265/?epa=SEARCH_BOX).
} 
strah od nerazumijevanja, strah roditelja da im liječnik neće vjerovati i sl. ${ }^{3}$ Neki od tih strahova vrlo konkretno zalaze u medicinsko područje, što ovaj rad ne može zahvatiti, te njih valja razmatrati u tom kontekstu iako će se dijelom ukazati i na nejasnoće (i strahove) koje, između ostalog, proizlaze i iz medicinske argumentacije.

Obje spomenute suprotstavljene strane posjeduju znanja (iako njihova znanja nemaju jednaki status) i argumente za svoju poziciju, svoje odluke i aktivnosti. Zagovornici cijepljenja pozivaju se na službeni stav biomedicine i "službenu" znanost. Time se implicira da postoji neslužbeni stav i neslužbena znanost, odnosno popularno ili čak iskustveno znanje. Clare Birchall (2006) osim osmišljene kategorije "popularnog znanja" kao opozicije legitimnijim znanjima, raspravlja o legitimnim i nelegitimnim znanjima. Ne zanima je nužno pitanje zašto se ljudi pored "službenih" znanja okreću popularnim znanjima, nego se pita koji je odnos između "službenih" i “neslužbenih" znanja (2006: xii). Popularnim znanjima smatra ona koja su onkraj (ne)istina, a za koja su ljudi spremni uložiti simbolički ili drugi kapital (usp. isto). Njima ne pristupa kao znanjima koja su sporedna ili izvanjska legitimnim znanjima, nego ih smatra znanjima koja sa službenima ostvaruju integralnu ulogu u njihovu oblikovanju, organiziranju, stvaranju, promicanju i plasiranju (isto: 21). Takva znanja promatra kao diskurzivne oblike popularne kulture koji sistematiziraju i kontekstualiziraju ideje o određenim događajima i svijetu (isto: 22) te nude razumijevanje svijeta nevezano za "službena" znanja, iako s njima u različitim odnosima (isto: 21). Smatra pritom da ne postoji neograničen prostor za različite konfiguracije znanja. Oni na višem položaju posjeduju utjecaj na to što znači znati i tko će imati pristup znanju i moći. S druge su strane znanja koja pokazuju otpor prema dominantnoj ideologiji (isto: 8). Tako su u hrvatskom medijskom prostoru znanja uvjetno podijeljena na službena i manje službena, u slučaju prijepora oko obaveze cijepljenja na tzv. google znanja. ${ }^{4}$ Istraživačka novinarka u području zdravstva i medicine Nataša Škaričić bavi se, među ostalim, i odnosom masovnih medija i medicine. Detektirala je u javnom diskursu dvije suprotstavljene skupine: navodno razumne zagovaratelje i legaliste te nerazumne antivaksere i opstruktore zakona (usp. Škaričić 2017a i 2017b). Pritom, zagovaratelji se pozivaju na znanost kojoj vjeruju dok se one koji sumnjaju, između ostalog, proziva da su protiv same znanosti i to baš zato jer

\footnotetext{
${ }^{3}$ Nakon provedenog istraživanja, na navedene primarne strahove i one koji iz njih proizlaze nadovezao se i "strah od progovaranja o cjepivima" te moj vlastiti "strah od pisanja o cjepivima". Naime, s obzirom na to da je tema u znatnoj mjeri obavijena pretpostavkama i predrasudama, kod nekih mojih ispitanika, prvenstveno onih koji vočavaju ili svjedoče propustima obavezne imunizacije, prisutan je strah od gubitka dostojanstva, društvenog statusa ili izigravanja ljudskih sloboda (usp. i Svendsen 2010: 15). Sve to može biti kompromitirano kritičnim i javnim promišljanjem cijepljenja. Također, i sama sam bila upozorena od nekih kolega da tema nije "progresivna", implicirajući da je stoga "nazadnjačka".

${ }^{4}$ Roditelje/skrbnike koji propituju cjepiva i/ili sustav cijepljenja naziva se često i pogrdno google roditeljima jer kad službenim znanjima nemaju pristupa ili im se čine nedovoljno uvjerljivima, svoje uvide u problematiku navodno otkrivaju na internetu, googlajući. Međutim, pejorativnost takvog prozivanja može biti promašena s obzirom na to da se internet može shvatiti kao velika knjižnica u kojoj je moguće doći do raznolikih informacija, ali i znanstveno ovjerenih podataka. Etiketa je još neobičnija kada se kao opoziciono djelovanje očekuje "povjerenje u one koji znaju". Također, kritike cijepljenju nisu samo suvremena pojava niti su nastale isključivo slobodnijim protokom informacija. Pojavljuju se uskoro nakon uvođenja cijepljenja u 19. stoljeću (usp. Wolfe i Sharp 2002).
} 
sumnjaju i propituju, jer ne vjeruju u znanost i njezine dosege pa se u komentarima raznih tekstova kao reakcije na objavljenu vijest na temu cijepljenja zaziva njihovo vraćanje u srednji vijek gdje navodno svojim primitivnim stavovima pripadaju. ${ }^{5}$ Zamjetno je ovdje izvrtanje paradigme pri kojemu upravo zagovaratelji tzv. znanstvenih istina tim istinama kao općeprihvaćenima vjeruju, prozivajući istovremeno "neuku" javnost koja sumnja za njihove nazadne, neliberalne, često i vjerske stavove. Zanimljivo je primijetiti da su u hrvatskom medijskom prostoru doista desno orijentirani mediji skloniji objavljivati vijesti koje podržavaju kritiku cijepljenja ili objavljuju loša iskustva roditelja nakon cijepljenja djeteta. $\mathrm{U}$ takvim objavama koje direktno ili indirektno dovode u pitanje opravdanost i/ili sigurnost cijepljenja izostaju argumenti koji bi se mogli povezati s vjerskim učenjima ili dogmama. ${ }^{6}$ Paradoksalno, navodi Škaričić, upravo liberalni mainstream mediji šire netrpeljivost prema kritičarima cijepljenja te su aktivni sudionici u oblikovanju agresivnog, prijetećeg i netolerantnog javnog diskursa. U objavama o cijepljenju, $\mathrm{u}$ ionako izrazito paternalističkom zdravstvenom sustavu, zagovaraju još više paternalizma i represije (usp. isto).?

Osim agresivnih polemika i prozivanja onih koji cijepljenje dovode u pitanje, u medijima se proizvode zastrašujući i prijeteći naslovi i sadržaji. Tako je već godinama prisutno (ne) opravdano zastrašivanje pojavom epidemije ospica. ${ }^{8}$ Ospice se prikazuju vrlo opasnom, u velikoj mjeri i smrtonosnom bolešću. Takvu definiciju često ne slijedi starija znanstvena literatura, u kojoj je moguće pronaći prednosti prebolijevanja dječjih bolesti, ${ }^{9}$ niti pojedina sjećanja starijih ispitanika koja ukazuju na promjenu definicije ospica, ali i na uskraćivanje mogućnosti prebolijevanja dječjih bolesti u optimalnoj dobi upravo cijepljenjem. Cilj ovoga rada, kao što je već navedeno, nije prosuđivati o istinitosti tvrdnji s obzirom na to da su

\footnotetext{
5 "Istina o cijepljenju" se u medijima ponekad prikazuje u toj mjeri konačnom i neupitnom da se deplasiraju pokušaji bilo kakve rasprave na tu temu (usp. npr. Barković 2018 i Jergović 2018).

${ }^{6}$ Autori koji objavljuju vijesti o naličjima cijepljenja koriste se često upravo antropološkim, fenomenološkim uvidima, prenoseći teška i tužna iskustva roditelja čija su djeca imala neželjene posljedice nakon cijepljenja i/ili njihovu borbu s nelogičnostima i apsurdima sustava (usp. npr. s. n. 2016; Bradarić 2015; posebno Borić 2018).

7 Usp. primjerice Tomić (2017, 2018), Bešker (2017), Dežulović (2017).

${ }^{8}$ Kada se u google tražilicu upiše sintagma epidemija ospica, proizlazi devedesetak zastrašujućih naslova u razdoblju od 2014. do 2019. godine koji velikim dijelom najavljuju skoru epidemiju: "Pitanje je dana kad će Hrvatsku poharati epidemija ospica" (dostupno na: https://www.index.hr/vijesti/clanak/pitanje-je-dana-kad-ce-hrvatsku-poharati-epidemija-ospica/1038997.aspx (pristup 11. 3. 2019.)); "Krene li se širiti epidemija ospica, svi smo ugroženi, čak i ako smo cijepljeni; Dr. Tešović: Razmatra se uvođenje i treće doze cjepiva, a necijepljenima prijete i druge bolesti" (dostupno na: https://slobodnadalmacija.hr/novosti/ hrvatska/clanak/id/550620/krene-li-se-siriti-epidemija-ospica-svi-smo-ugrozeni-cak-i-ako-smo-cijepljeni-dr-tesovic-razmatra-se-uvoenje-i-trece-doze-cjepiva-a-necijepljenima-prijete-i-druge-bolesti (pristup 11. 3. 2019.)); “Liječnici: 'Imamo najgoru epidemiju ospica od 90-ih'” (dostupno na: https://www.express.hr/ znanost/lijecnici-imamo-najgoru-epidemiju-ospica-od-90-ih-17274 (pristup 11. 3. 2019.)). Epidemije inače proglašava ministar zdravstva na prijedlog Hrvatskog zavoda za javno zdravstvo temeljem Zakona o zaštiti pučanstva od zaraznih bolesti (čl. 2.), a to se, unatoč višegodišnjim najavama, još nije dogodilo.

9 Josip Fališevac u knjizi iz 1979. godine navodi da se već novorođenče rađa s imunitetom protiv nekih dječjih bolesti koji je nastao prijelazom protutijela iz krvi majke u krv djeteta. Naravno, onih koje je i ako je majka prirodno preboljela (usp. Fališevac 1979). Naime, dječje bolesti protiv kojih se cijepe djeca u dobi kada je njihovo prebolijevanje za njih najbezazlenije mnogo su opasnije za novorođenčad i odrasle, posebno stare ljude koji se protiv njih nisu cijepili ili ih nisu preboljeli. Međutim, oni koji su ih preboljeli, time su, u pravilu, stekli trajan imunitet te su aktivni sudionici u očuvanju kolektivnog imuniteta (v. kasnije u tekstu).
} 
one medicinske kvalifikacije bolesti, premda su do neke mjere povijesno promjenjive i kulturološki uvjetovane (v. npr. Prout 2005: 136-141). Također, moji sugovornici iznosili su iskustveno znanje o bolestima koje je njihov osobni doživljaj bolesti i njezine složenosti te takvo znanje nije moguće uključiti u neki tip generalizacije.

To vam je nekad bila dječja bolest, tako kako naziv kaže, poželjno preboljeti u dječjoj dobi, a ne da dobiš posle kad više nije tak bezazleno. (K. N.)

Ako bi se netko trebao cijepiti, to su odrasli koji ospice nisu preboljeli. Oni su u opasnosti, a ne djeca. (M. S.)

Cijepljenjem se dječje bolesti odgađaju u stariju dob i to je opasno. Mene brine što će se dogoditi kada nam izumre generacija koja je dječje bolesti preboljela u djetinjstvu. Tek će tada nastupiti epidemije jer neće biti onih koji nam danas čuvaju imunitet krda. (B. S.)

Mi smo sve te dječje bolesti nekad pod normalno "odrađivali". Ko je dobil ospice ili vodene kozice ili mumps, išli smo se $k$ njemu igrati da svi to dobimo i toga se rješimo, pa tak je i doktor mami govoril. (M. Ž.)

Sjećam se da je doktor mami govorio kak je dobro da smo mi klinci odradili te dječje bolesti jer će nam sad kompletan imunitet biti jači, da je to dobro za imunitet. Danas po novinama i televiziji pričaju sasma nekaj drugo. (B. E.)

Ne poznajem nikoga da je umro od ospica, a svi smo ih imali i nije bilo epidemija. Pa, to je bilo normalno. I nismo ih se bojali. (Ž. S.)

Sad kad postoje cjepiva strah od ospica je veći nego ikada. Definitivno veći nego u vrijeme kada cjepiva nije bilo, kada se nitko nije bojao ospica. (M. M.)

Smiješno je to. Prvo su nas cijepili s jednom dozom, pa se pokazalo da nije dovoljno pa nas cijepe s dvije doze. Sad je jasno da niti to ne djeluje. Razbolijevaju se odrasli cijepljeni s dvije doze. Pretpostavljam da će uskoro početi propagirati treću pa četvrtu i uskoro ćemo se cijepiti doživotno i uvjetovat će nam zaposlenjem. (M. A.)

Upravo na primjeru različitih kvalifikacija bolesti u različitim povijesnim razdobljima i različitim diskursima (medicinski, svakodnevni, medijski) možemo uočiti "proces selekcije [informacija] u kojem se nekom riziku pripisuje velika važnost, dok se druge zanemaruje" (Svendsen 2010: 66), odnosno prijepori, između ostalog, nastaju kada se negativne posljedice cijepljenja ignoriraju i prešućuju u korist diskursa o prednostima cijepljenja. ${ }^{10}$ Uočljivo je i da mediji češće izvještavaju o potencijalnim epidemijama od onih bolesti koje

\footnotetext{
${ }^{10}$ Ukazivanja na propuste u sustavu cijepljenja ili pojavnost nuspojava često ostaju bez odgovora. Primjerice dr. med. Alma Demirović, čije je dijete nakon cijepljenja cjepivom dTpa-R (Reforco) tj. Refortrix u svibnju 2017. godine razvilo nuspojavu u vidu alopecije areate, postavila je u ožujku 2018. godine na facebook stranici Udruge za zaštitu pacijenata pismo u kojem ukazuje na određene propuste u sustavu cijepljenja te postavlja pitanja Udruzi kojima moli "za mišljenje i prijedlog konkretnih mjera koje vaša Udruga može poduzeti kako bi se navedeni sustav cijepljenja i njegova sigurnost poboljšali i kako bi se građanima povratila vjera u struku” i "uputu što nam je činiti kako bismo ostvarili temeljno pravo pacijenta, a to je pravo na adekvatan tretman djeteta koje je pretrpjelo tešku nuspojavu nakon cijepljenja, a koje nije bilo temeljeno na slobodnoj odluci već na zakonskoj obavezi?". Objava je obrisana, a autorica blokirana. Pismo je potom objavljeno na facebook stranici Glupače, stranici koja objavljuje iskustva roditelja čija su djeca pretrpjela neželjene posljedice cijepljenja.
} 
se nalaze u kalendaru cijepljenja ili za njih postoji cjepivo. Medijska brojnost takvih tekstova može izazvati (ne)opravdan strah od nečega od čega ili nema direktne, trenutne opasnosti ili je vrlo mala vjerojatnost da će se opasnost ostvariti. Naime, "bilo što se može prikazati opasnim, uz uvjet da se informacija iznosi na dovoljno jednostran način" (isto: 22), a na spomenuti način se proizvodi slika prema kojoj se "potencijalne opasnosti prikazuju kao da su aktualne opasnosti" (isto: 23, istaknuo L. S.; usp. i bilj. 9).

Važno je napomenuti da su, prema mojem istraživanju, kritičari politike cijepljenja izrazito heterogena skupina (aktivista, ali i "običnih" roditelja), s potpuno različitim stavovima, motivima i argumentima (usp. i Škaričić 2017b). Unatoč tome, često su okarakterizirani teoretičarima zavjera11 i pejorativno prozvani antivakserima. ${ }^{12}$ Terminom antivakser zahvaćena je zapravo nejasno definirana i vrlo široka kategorija u koju su uključeni svi oni koji na različite načine iz različitih razloga upućuju kritiku politici i sustavu cijepljenja, cjepivu, medicini ili farmaciji (vezano za cijepljenje), a paradoksalno je da najčešće nisu protivnici ideje cijepljenja kako naziv sugerira, odnosno nemaju ambicije nekome uskraćivati cijepljenje ili ga ukidati. Termin je etiketa koju zagovornici cijepljenja dodjeljuju kritičarima cijepljenja. Jedini antivakseri među njima, kako navode neki moji sugovornici, zapravo su exvakseri.

Znate, velika većina ljudi koji su izgubili povjerenje u sustav procjepljivanja zapravo su exvakseri, a ne antivakseri. Svi smo mi bili vakseri, vjerovali liječnicima i sustavu, dok ti se ne dogodi sranje i shvatiš da ako o uzroku bolesti svoga djeteta govoriš iskreno, automatski postaješ nekakav antivakser, i svi te drže budalom i zato im to prolazi jer smo mi budale, a oni su stručni i pametni i onda si ti, oštećen, još i kriv i lud jer kao, lupetaš protiv njihove konačne znanosti. (P. I.)

Još ću vam nešto reći. Mi kakti antivakseri smo svi prvo uredno bili vakseri i vakseri nekad postaju antivakseri ili exvakseri, ali nikad obrnuto, za to još nisam čula, da su uspjeli ljudima objasniti i uvjeriti ih da su u krivu. (V. B.)

Ujedno, kritičari cijepljenja nazivaju se nerazumnima, neukima, medicinski nepismenima, sebičnima i zapravo opasnima za "razumnu većinu" (Škaričić 2017b). Njihovi protivnici optužuju ih da su protiv javnog zdravlja/zdravstva i kao takvi izloženi su podsmjehu, osudama, napadima, diskreditiranju, prijavama i, u konačnici, sankcijama. Isti tretman često u javnom diskursu i na društvenim mrežama imaju i neki medicinski stručnjaci. Naime, njihov je medicinski autoritet neupitan jedino kada bezuvjetno zagovaraju cijepljenje. Oni koji preispituju politiku cijepljenja, pa bili i medicinski stručnjaci, mogu biti prozvani ne-

${ }^{11}$ Propitivanje ideje cijepljenja često je okarakterizirano teorijom zavjere isključivo u negativnom kontekstu, iako same teorije zavjera (kada to i jesu) ne moraju nužno biti sulude, nelogične, paranormalne ili paranoidne. Suzana Marjanić primjerice jednom od vrijednosti u teorijama zavjera iščitava "subverzivne potencijale s obzirom da propituju strategije moći na vlasti” (Marjanić 2016: 114), a Jack Bratich (2008) napominje da se one ne mogu promatrati neovisno od stvarnosti iz koje nastaju. Naprotiv, one su "portali u kontekst koji ih problematizira" (Bratich 2008: 19 prema Marković 2018: 267) te se mogu čitati isključivo u odnosu na njihovu vanjsku diskurzivnu poziciju (Marković 2018: 266).

${ }^{12}$ Navodne se antivaksere $u$ javnom diskursu često svrstava $u$ istu, pejorativno osmišljenu kategoriju s tzv. ravnozemljašima, "gušterima" Davida Ickea, različitim alternativcima, primitivcima i ultradesničarima, odnosno onima koji (zatucano) vjeruju u neznanstveno, natprirodno, neobjašnjivo i iracionalno. 
stručnim "pseudoznanstvenicima”, a njihova specijalizacija neodgovarajućom, bez obzira na izostajanje istih zamjerki zagovornicima cijepljenja. ${ }^{13}$

U radu je spomenuta heterogena skupina smještena $u$ središte pozornosti ne samo zato što je riječ o skupini koja uznemiruje dominantni diskurs nego i zato što ta skupina akumulira različite strahove koji su posljedica sumnji, nepovjerenja, (ne)informiranosti. Također, u postojećem sustavu procjepljivanja djece, njihovi su strahovi dominantniji u javnom diskursu od strahova onih koji s povjerenjem u sustav redovito cijepe djecu. ${ }^{14} \mathrm{Na}$ zabrinutost potonjih vezanu za pad procijepljenosti i potencijalne rizike koji bi iz takvoga stanja mogli proizaći, osim straha, u većoj se mjeri nadovezalo zamjeranje, pa i ljutnja usmjerena na one koji na bilo koji način spore i/ili propituju procjepljivanje djece. Njihovi strahovi odnose se posebno na strah od kompromitiranja imuniteta kolektiva, iz kojeg proizlazi strah od narušavanja javnog zdravlja, odnosno strah od osobne ugroze ili ugroze njihove djece. ${ }^{15}$

${ }^{13}$ Primjerice, stručnost liječnika iz Dubrovnika dovedena je u pitanje nakon javnog ukazivanja na potencijalne rizike cijepljenja. O tome govore neki od komentara ispod novinskog članka naslovljenog "Imamo jedno pitanje; kako ovaj gospodin koji tvrdi da je cijepljenje užas još radi kao doktor opće prakse u Dubrovniku?" (Vlašić 2018): "zatucani desničari sve liječe svetom vodicom... taj brico iz malog mista može cuckima bodlje od ježa iz nogu vaditi... za sve ostalo je sramota medicine"; "Najmanje što se može jest poslati ga na obnovu licence. Neka ponovno polaže imunologiju. Mada bi bilo najbolje oduzeti mu licencu jer ovakav šarlatan nema što raditi u bolnici”; "Oduzeti dozvolu za rad! Ovo je sramota struke”. Ispod istog teksta nalazi se i ovaj komentar: "to je ono, kad se prica protiv cjepljenja onda cete rec da ne postoje doktori koji su protiv cjepljenja. a kad se javi neki doktor protiv cjepljenja, onda cete rec da covjek ne moze bit doktor jer prica protiv cjepljenja!!!” Također, Lidiju Gajski, autoricu knjige Lijekovi ili priča o obmani, u kojoj, između ostalog, kritički promatra politiku cijepljenja, struka je optužila da dezinformira javnost i iznosi netočne tvrdnje te ju je prozvala nekompetentnom, korumpiranom i prijetnjom kolektivnom zdravlju. U rujnu 2012. godine predstojnik odjela za cijepljenje Hrvatskog zavoda za javno zdravlje, prim. dr. sc. Bernard Kaić, podnio je Hrvatskoj liječničkoj komori i njezinom Sudu časti zahtjev za pokretanje disciplinskog postupka protiv dr. Lidije Gajski. U studenom iste godine Povjerenstvo za medicinsku etiku i deontologiju Hrvatske liječničke komore Zahtjev je ocijenilo neosnovanim i odbacilo (usp. Očitovanje). Težnju ostvarivanja jednoumlja, homogenosti i poslušnosti u vlastitim redovima, ignoriranje kritike te sklonost diskreditaciji neistomišljenika, čak i iz vlastitih redova, uočila je u analizi diskursa zapadne medicine kao službene zagovornice politike cijepljenja Mateja Černič (2014: 22-31), iako valja napomenuti da se od njezine studije Ideološki konstrukti cijepljenja ogradilo Slovensko sociološko društvo i donijelo negativnu kritiku, navodeći kao razloge metodološke propuste, pristranost, ali i izostanak medicinske recenzije. Međutim, nekoliko je recenzija upravo medicinskog profila, dostupnih na stranicama knjige (https://www.ideoloski-konstrukti.com/recenzije/), studiju ocijenilo pozitivno. Oprečne ocjene iste studije govore o izrazitoj podijeljenosti stručnih interpretacija, ali mogu ostavljati i dojam da se recenzije pišu i s obzirom na to koja se strana u vezi cijepljenja primarno zastupa.

${ }^{14}$ I u toj skupini ima onih koji artikuliraju probleme sa sustavom, a oni se uglavnom odnose na težu dostupnost (fizičku i financijsku) elektivnih cjepiva (onih izvan obaveznog kalendara cijepljenja). Također, valja istaknuti i skupinu zagovornika cijepljenja koja načelno ima povjerenje u službene preporuke struke, ali istovremeno ne uvažava preporuke i mišljenja medicinskih stručnjaka kada oni uključuju (pojačani) oprez prema cjepivima i/ili izostavljanje pojedinih (uglavnom elektivnih) cjepiva:

"Rekla nam je pedijatrica nakon cijepljenja da bi trebalo izbjegavati javna mjesta s puno djece i da bi bilo dobro da dijete ostane $u$ izolaciji da ne prenese virus iz cjepiva na drugu djecu. Raspitala sam se o tome $u$ genijalnoj grupi na facebooku i saznala da pedijatrica priča gluposti i da to nije moguće." (P. Ž.)

"Mali je nakon MMR-a dobio trombocitopeniju i pedijatrica je zaključila da bi to moglo biti od cjepiva i da je to znak za pojačani oprez. Od onda nikako da ga opet cijepi, koliko god ju ja nagovarala. Sutra to idem obaviti privatno." (J. Š.)

${ }^{15}$ Primjerice, nakon novinskog članka "Skandalozno Otvoreno: 'Kako znamo da cijepljenje ne uzrokuje epidemije?”, uslijedili su neki od komentara (usp. s. n. 2018): “Ne morate vi cijepiti ni sebe ni svoju djecu ili 
[...] Sve vas antivakserske degenerike treba lisiti zdravstvenog osiguranja, pa onda lecite sebe i decu kod sarlatana lipozomalnim vit c i ostalim pizdarijama. Licemeri, cim vam nesto fali odmah trcite kod tih istih doktora cije misljenje ne uvazavate. (na stranicama facebook grupe Cijepljenje/Vakcinacija - grupa za sve koji imaju pitanja i nedoumice, https://www.facebook.com/groups/459227237920265/search/?query=ana\%20 fir\%C5\%A1t\&epa=SEARCH_BOX)

[...] koja ste vi glupača! Draže vam je da dijete oboli od bolesti koja se može itekako zakomplicirati nego da plače 5 min jer je primilo injekciju? Vodite ga na kozice party? Možete i na pertusis party čujem da ga u našim krajevima ima. Vodite ga na gripa party to je trenutno in. Vi ste dokaz da bi se svi trebali psihološki testirati prije nego što postanu roditelji čisto da se vidi dal su podobni. Koja normalna osoba koja se naziva majkom namjerno zaražuje svoje djete? Idi zuri u sunce i liječi se vitaminom c da konačno prirodna selekcija odradi svoje. I da takvima poput vas treba oduzeti djecu. (na stranicama facebook grupe Cijepljenje/Vakcinacija - grupa za sve koji imaju pitanja i nedoumice, https://www.facebook.com/groups/459227237920265/search/?query=ana\%20 fir\%C5\%A1t\&epa=SEARCH_BOX)

S takvim retardima ne želim imati posla, ne želim slušati njihove glupe argumente, njihove vječne žalopojke nit ih želim u blizini svoje djece. Za njih je neki Goli otok, miči ih dalje od mene i svih normalnih ljudi koji vjeruju u znanost. (V. J.)

To su licemjeri, takvima treba oduzeti djecu bez rasprave, a njih zatvoriti bez pomilovanja. (G. H)

Da, cjepivo je rizik pa nek ga preuzme netko drugi? Valjda ja? Moje dijete? Za njihovu djecu? Koji odvratnjaci! (E. M.)

Jako mi smetaju takvi ljudi. Neki čak i ne kuže imunitet krda pa misle da su prebolijevanjem dječje bolesti uhvatili neki super imunitet koji će ih spasiti od rakova i kojekakvih drugih bolesti. Navodno takvim imunitetom čak pridonose stvaranju imuniteta krda! Takve tek ne možeš u ništa uvjeriti jer oni niti ne kuže koja su ugroza za druge. (P. R.)

Ne samo da su sebični. Oni su, doslovno, ubojice. Ja sam imunokompromitirana osoba i ne smijem se cijepiti, moj život ovisi o imunitetu krda, a ovisim o budalama koje ne cijepe djecu zbog gluposti. (J. M.)

\footnotetext{
unučad, ali molim vas zatvorite ih onda doma u 4 zida, da ne ugrožavaju moju. Ma sram vas sve bilo. Nekada je u školu došao liječnik i medicinska sestra, pocijepili su sve što hoda i ne sjećam se da je neko obolio"; “i zemlja je ravna... ma neka, kad već nema ratova da regulira ljudsku populaciju bude to njihova glupost napravila. uostalon nema frke ako nećeš cijepiti i dijete dobije bolest koja se mogla izbjeći cijepljenjem sam snosi troškove njegovog liječnja a ne prek zdrastvenog. svako ima pravo na odluku ali zašto bi društvo plačalo glupe odluke”; “Roditelj koji ne cijepi svoje dijete je neodgovoran nazadan i sebičan”; “Ne, ne bi svatko trebao imati pravo glasa i mišljenja oko cjepiva, jer nemate pojma o čemu pričate. Ne znate osnovne stvari kao što su antigeni, iz biologije ste imali trojku, ali ćete sada pročitati 2 bloga i ponavljati da 'cjepivo ima u sebi živu!' i nemate niti ideju koliko ste neuki i koliko je loše to što radite. Niste u stanju bili savladati biologiju u srednjoj školi, ali mislite da možete parirati doktorima koji studiraju po 15+ godina. Prokleti maloumnici. Zahvaljujući cjepivima je danas čovječanstvo gdje je. Da nema cjepiva, bili bismo još uvijek u borbi protiv kuge, dječje paralize, i ospica".
} 


\section{POVJERENJE U ZNANOST}

Dio retorike alopatske medicine kao službene zagovornice politike procjepljivanja djece pozivanje je na povjerenje $u$ znanost što implicira povjerenje pacijenta prema liječniku. Pozivanje na povjerenje u dosege biomedicine kontradiktorno je ideji znanosti i sličnije religijskom mišljenju, odnosno svojevrsnom sustavu vjerovanja ili ideologiji. Još je Michel Foucault (2009) u medicinskom ophođenju primijetio sustav vjerovanja koji se oblikovao i razvijao u društvenim procesima pomoću političkih i interesnih odnosa između medicinske struke i nacionalne države. Unatoč reputaciji objektivne i racionalne znanosti, neki su znanstvenici uočili sakralnost i ritualnost (Kleinman 1980), odnosno prožetost medicine duhom religije (Domaradzki 2013). Jan Domaradzki medicinu promatra kao sekularizirani oblik religije koji je preuzeo njezine društvene funkcije. Uspoređuje strukturu Rimokatoličke crkve i Svjetske zdravstvene organizacije (World Health Organization) te njihovu sličnost u funkcioniranju: obje su u čovjekovu životu od rođenja do smrti, nude odgovore na iste strahove, obje nameću osjećaj doživotne ovisnosti, obje su visoko birokratizirane, hijerarhizirane i netransparentne (Domaradzki 2013: 31). Ljudi se rađaju nesavršeni, pokvareni i trebaju zaštitu medicine, a cijepljenje je ritual čišćenja od pogubnih virusa i bakterija (isto: 27). Preko monopola nad zdravljem, bolesti i ljudskim tijelom medicina nameće nadzor nad svim dimenzijama svakodnevnog života. U ime zdravlja sekularna crkva uvjerava, obraća, a ako je potrebno zastrašuje, zabranjuje i kažnjava (isto: 31$)^{16}$

Neprestanom prijetnjom kaznom (u slučaju odbijanja ili odgađanja cijepljenja) podržava se strah, a u kulturi straha loši su uvjeti za povjerenje na koje se poziva. Strah na povjerenje djeluje potkopavajuće, kad se povjerenje smanjuje, pojačava se djelokrug straha. Tako, rastući strah može biti i posljedica i uzrok opadajućeg povjerenja (Svendsen 2010: 129-135). Naime, "[a]ntonim povjerenja nije nepovjerenje", nego strah (Horton 2017). Strah je moćan, a strah koji može imati raširene reperkusije i odjeke, koji može diktirati javnu politiku, omogućiti moć pojedinim grupama i drugima je oduzeti, koji može rušiti i stvarati zakone, Robin Corey naziva političkim strahom, a definira ga kao ljudsko poimanje određene štete njihovu kolektivnom opstanku ili njihovoj kolektivnoj dobrobiti (2004: 2). Istovremeno, inzistiranje na povjerenju (u struku) usko je povezano s rizikom, bio taj rizik spoznat ili ne. Kada se nekome ukazuje povjerenje, pretpostavka je da izloženost i ranjivost koja iz toga proizlazi neće biti iskorištena i zloupotrijebljena jer se povjerenjem dijelom zanemaruju eventualni negativni scenariji - ili se barem pretpostavlja da oni neće nastupiti. ${ }^{17}$ Samo

\footnotetext{
${ }^{16}$ Sociolog Richard Sennett navodi da "[i]nstitucija može vladati kao jedini izvor autoriteta, a vjera može služiti kao jedini standard mjerenja stvarnosti” (prema Salecl 2012: 14).

17 Službena medicina ne negira potencijalne rizike cijepljenja tvrdeći istovremeno da su cjepiva sigurna ( $v$. dalje u tekstu o rizicima cijepljenja). Upute o lijeku jasno potvrđuju rizike cijepljenja. Primjerice, kao česte nuspojave zabilježene tijekom kliničkih ispitivanja za cjepivo Priorix, protiv morbila, parotitisa i rubele, navedene su, između ostalih, "infekcije gornjih dišnih putova”, a manje česte "infekcije srednjeg uha, oticanje limfnih žlijezda, gubitak teka, razdražljivost, neuobičajen plač, nemogućnost spavanja (nesanica), konjunktivitis, bronhitis, oticanje parotidnih žlijezda". Također, "nakon stavljanja cjepiva Priorix u promet, u nekoliko slučaja zabilježene su i sljedeće nuspojave: iznenadne, po život opasne alergijske reakcije”, "infekcija ili upala mozga, leđne moždine i perifernih živaca", "upala nekih živaca, moguće s trncima ili osjećajem peckanja ili gubitkom
} 
povjerenje stoga može predstavljati rizik, posebno ako se rizik zanemaruje, prešućuje, omalovažava ili ignorira (usp. Svendsen 2010: 129).

Paralelni razvoj biomedicine i kulturno specifične ideje znanstvene racionalnosti nastale u zapadnim zemljama iznjedrio je, prema Mattingly (1998), viziju objektivne znanstvene medicine koja barata navodno neutralnim znanstvenim činjenicama i biološkim univerzalijama. Međutim, brojne su kulturnoantropološke studije pokazale da su biomedicinske epistemološke pretpostavke o prirodi bolesti kao i biomedicinsko razumijevanje liječenja društveno konstruirani načini razumijevanja bolesti (usp. Čapo 2017: 223). Dominantna paradigma cijepljenja u službenoj alopatskoj medicini, kao što je navedeno, teško podnosi kritiku te stoga rijetko potiče reviziju, a dalje u tekstu pojasnit će se njezina otuđenost od životnih iskustava djece i roditelja nakon cijepljenja te utoliko nalikuje i na ideologiju. Za opstanak neke ideologije "nije nužno da je ljudi aktivno podržavaju ili u nju vjeruju. Ključno je da ne iskazuju sumnje. Kako bismo se ravnali prema stavu većine, potrebno je samo vjerovati da takva većina vjeruje. Ideologije stoga uspijevaju zbog 'vjerovanja u vjerovanje drugih”" (Salecl 2012: 16-17), odnosno vjerujemo jer vjeruju liječnici.18 Nevjerovanje ili nepovjerenje poželjno je zadržati za sebe i ne iskazivati javno. Također, i ideologija izbora kao i ideologija nametanja imaju slične društvene učinke. Obje djeluju tako da, više ili manje očito, onemogućuju djelovanje pojedinaca, čak i onda ako je u pitanju vlastito tijelo i vlastito zdravlje. Uspjeh promicanja ideologije izbora u postindustrijskom kapitalizmu, reći će Renata Salecl, "sastoji se u tome da je ljude učinila slijepima za činjenicu da [...] su pitanja [...] zdravlja i sigurnosti kao i okoliša smještena daleko od mogućnosti da o njima odlučuju. Stoga na razini društva gubimo izbor glede promjene u odnosima moći" (isto: 170) ili izbor o važnim životnim pitanjima kakvo je zdravlje djeteta odnosno cijepljenje.

\section{PREVENCIJA I NJEZINI RIZICI}

Preventivni princip kao temeljno uporište cijepljenja podržava ideju koja bi se mogla sažeti u raširenoj poslovici "bolje spriječiti nego liječiti” (Svendsen 2010: 86), kojoj se u slučaju cijepljenja može sučeliti i ona: "što bi bilo, kad bi bilo...". Bolest je nešto što pod svaku cijenu želimo izbjeći. Cijena izbjegavanja bolesti svakako nije bolest sama. Razumljiv je stav da "bolest i patnja postavljaju moralna i egzistencijalna pitanja" (Čapo 2017: 222), međutim manje je razumljivo da ista ili srodna pitanja postavlja i imperativ (očuvanja) zdravlja. Naime, dva središnja aspekta preventivnog principa tiču se nesigurnosti i štete

osjeta ili normalne pokretljivosti (sindrom Guillain-Barré)", pa i "sindrom sličan parotitisu ili morbilima" (HALMED, Baza lijekova). Također, na službenim stranicama Centra za kontrolu i prevenciju bolesti, američkog CDC-a, za gotovo svako nabrojano cjepivo kao moguća posljedica cijepljenja navedena je napomena: "Kao i za svaki lijek, postoji vrlo mala vjerojatnost da će cjepivo uzrokovati ozbiljno oštećenje ili smrt” (CDC Vaccines and Immunizations, https://www.cdc.gov/vaccines/vac-gen/side-effects.htm).

18 Infektolog prof. dr. Goran Tešović primjerice javno artikulira: "Moji kolege [...] vjeruju u učinkovitost programa i vjeruju u neškodljivost i beneficije cijepljenja” (s. n. 2017, istaknula autorica). 
(Svendsen 2010: 87), a nastojanja da se smanje opasnosti mogu ih zapravo i povećati. U svijetu preventivnog principa budućnost može biti određena opasnostima, a ne samo mogućnostima. Ukoliko se spriječi jedna prijetnja, uvijek postoji beskonačnost novih. Nepostojeća je granica suzbijanja opasnosti, a "svaka mjera za ograničavanje opasnosti po zdravlje u sebi sadrži nove opasnosti” (isto: 91). Primjerice, sve veći broj medicinskih terapija danas se usmjerava prema tzv. ijatrogenim bolestima, odnosno bolestima koje su prouzrokovane ranijom medicinskom terapijom, a medicinska tehnologija koja nam pomaže može nas istovremeno i zastrašivati (isto: 77-78). Na tim se mjestima isprepliće čvor koji se u raspravama o cjepivu dovodi do krajnjih konzekvenci.

Dalje u tekstu navodit ću neke od prijepornih točaka koje se susreću u raspravama na društvenim mrežama, a koje spominju i moji sugovornici. Postupak koji nije kurativna, nego tek preventivna mjera ne bi u toj mjeri dovodili u pitanje da nije vezan za represivnu mjeru i da se u znatnoj mjeri ne provodi neselektivno. Naime, djeca se često cijepe bez obzira na individualnu osjetljivost na pojedine sastojke cjepiva, povijest bolesti ili genetsku sliku. ${ }^{19}$ lako postoji načelno zalaganje za boljom komunikacijom između roditelja i liječnika-cjepitelja (usp. Pelčić 2016), moji su sugovornici posebno problematičnim istaknuli sustav procjepljivanja djece u kojem im se uskraćuju temeljne informacije. Naime, kada roditelji dovode djecu na cijepljenje, u pravilu im se ne podastiru informacije o sastavu cjepiva, njegovim nuspojavama i kontraindikacijama, a ukoliko sami traže podatke, često nailaze na otpor.

Čula sam da burno reagira na bilo kakva pitanja u vezi cijepljenja i dugo sam razmišljala kako pristupiti i pitati sve što me zabrinjava. Već sam i sanjala o tome. Živjela u silnom strahu i neizvjesnosti. Na kraju sam izabrala samo jedno pitanje: može li moje dijete imati nuspojavu nakon cijepljenja? Rekla je da ne može, da su nuspojave u glavama antivaksera, a ne u praksi, a neću zaboraviti niti da me pitala jesam li i ja jedna od onih kojoj se posvuda pričinjaju autistična djeca. (Ž. S)

Pitali smo za naziv lijeka, proizvođača, sastav i potencijalne loše posljedice. Bio je ljubazan i objasnio nam da ima prenatrpanu ambulantu, to nije njegov posao, da je nemoguće da on nama i drugim roditeljima objašnjava detalje o cjepivima, njegov je posao cijepiti po kalendaru. (J. K.)

Rekao je da cjepiva sigurno ne bi bila u kalendaru da su loša, da postoje silne službe i institucije koje o tome brinu i da ne moramo razbijati glavu stvarima koje su van našeg dosega. (M. I.)

Tražili smo papir uz cjepivo. Pitao nas je kaj smo i mi antivakseri i komentirao da previše čitamo gluposti. (J. Ć.)

Sastavili smo popis pitanja koja nas zabrinjavaju u vezi cijepljenja našeg djeteta. Pedijatrica nije htjela niti pogledati. Rekla je da ona cijepiti mora, takav je zakon, a ako ne želimo, prijavit će nas. (I. Z.)

${ }^{19}$ Ova je praksa najevidentnija u rodilištima gdje se, osim eventualno nedonoščadi, cijepi sva novorođenčad. 
"Bez straha, ne treba vam nikakva uputa", s osmjehom nas je tješila. "Ukoliko se pojavi temperatura, skinut ćete lijekovima, a ako otekne na mjestu uboda, stavljajte hladne obloge i to je to, ništa se drugo ne može dogoditi, osim što će vam dijete biti zaštićeno". (L. H.)

Činjenica jest da u uputama o lijeku stoje neke od ovih rečenica: "Pažljivo pročitajte uputu prije nego Vaše dijete primi ovo cjepivo", ili “Uputa sadrži Vama važne podatke" te "Ako imate dodatnih pitanja, upitajte liječnika ili ljekarnika". Postupak u kojem se ne traži pristanak roditelja, a informacije se iznose selektivno (najčešće predstavljanjem samo pozitivnih učinaka te izostavljanjem negativnih), ne može se smatrati informiranim postupkom, iako prema Zakonu o zaštiti pacijenata liječnik pacijentu ne smije uskratiti pravo na obaviještenost što bi trebalo uključivati informirani pristanak, odnosno upoznavanje sa svim koristima, rizicima cijepljenja i alternativom. ${ }^{20} \mathrm{U}$ emisiji Tema dana Hrvatske radiotelevizije, emitiranoj 9. travnja 2017. godine, prof. dr. sc. Goran Tešović potvrđuje da "nema informiranog pristanka prije cijepljenja. To je točno". Mnogi roditelji, pritom, kada traže informacije nailaze na prijetnje, zastrašivanja i uvjetovanja, a samo postavljanje pitanja interpretira se ponekad kao preispitivanje autoriteta liječnika.

Postavila sam hrpu pitanja, da me zanima čega sve ima u cjepivu, u kojoj mjeri štiti, jer se po novinama piše da ti to šta si cijepljen niš ne znači ako nisu cijepljeni svi oko tebe, da šta nije to premalo dijete, nije li to opasno za njega i tak... Odgovorio je da on nema vremena mene podučavati, zakon nalaže da mora cijepiti, ako ne želim, prijavit će me socijalnoj službi i gotovo. (M. S.)

Dugo smo odgađali cjepivo jer je mali bio boležljiv. Nikada nismo rekli da odbijamo cijepiti. Na jednom pregledu je rekla da tako više ne može, ili ćemo cijepiti ili nas mora prijaviti, i njoj sjede za vratom, dolaze inspekcije i ne može više tako. (K. K.)

Pripremili smo vlastiti popis pitanja koja nas zanimaju u vezi cijepljenja. Nije nas saslušao. Rekao je sestri da pripremi dokument koji ćemo potpisati da odbijamo cijepiti. Pokušali smo objasniti da ne odbijamo, nego smo zabrinuti i da smatramo da imamo pravo znati. Odgovorio je da nam dijete tako neće moći u vrtić, da moramo potpisati i neka ga više ne dovodimo u takvu neugodnu situaciju. (J. Ć.)

Smireno nam je objasnila da ako ne cijepimo dijete, ono više ne može biti njezin pacijent, neka nađemo nekoga kome se dâ s nama natezati. (D. I.)

Mene jucer pedijatrica "zamolila" da nadjem drugog pedijatra za svoje dijete da ne ugrozi necijepljene. Na moje pitanje da sto ako ne nadjem drugog pedijatra odgovorila mi je da moram preuzeti odgovornost za svoje dijete. Slozio sam se a njom i rekao joj da bas iz tog razloga ne zelim cijepiti moje dijete jer je ono moja odgovornost a ne cijepiti pa da nitko ne odgovara, da bi na kraju rekla da ne zeli raspravljati. (na facebook stranici Cijepljenje - pravo izbora)

Pitala sam protiv čega se danas cijepi, rekla je, to vam je mali koktelčić, sve je u redu,

20 Pacijent ima pravo na obaviještenost prema Zakonu o zdravstvenoj zaštiti (NN 150/08, članak 22., točka 6.) i Zakonu o zaštiti prava pacijenata (NN 169/04, članci 6., 8. 16. i 17.). Također, prema kaznenom zakonu samovoljno liječenje kazneno je djelo (NN 110/97, članak 241., točke 1. i 2.). 
ne brinite, pa sam pitala kako ona zna da će sve biti u redu. Rekla je da ima dovoljno iskustva. Ipak sam inzistirala da mi objasni što se sve može dogoditi. Rekla je, ništa, samo blaga temperaturica. Onda sam pitala da bi htjela vidjeti nekakav papir koji ide uz taj koktelčić. Tad se baš naljutila i rekla: "Šta sam ja sad na ispitivanju? Vi mene provjeravate ili ćemo cijepiti dijete?" (J. P.)

No, ipak, iako roditelji o tome često nisu obaviješteni, podaci o sastavu cjepiva, nuspojavama cijepljenja te eventualnim kontraindikacijama za cijepljenje nalaze se na stranicama HALMED-a (Agencije za lijekove i medicinske proizvode) i donekle mogu ponuditi neke odgovore o sigurnosti i učinkovitosti cjepiva. ${ }^{21} \mathrm{U}$ uputama svakog cjepiva nalaze se rečenice:

Kao i sva cjepiva, niti ovo cjepivo ne pruža potpunu zaštitu u sve djece koja se cijepe. Vaše dijete se ne smije cijepiti ako je alergično (preosjetljivo) na djelatne tvari ili bilo koji drugi sastojak cjepiva. Preosjetljivost na djelatne tvari ili neku od pomoćnih tvari iz proizvodnje cjepiva, kontraindikacije su cijepljenja.

Ovdje valja napomenuti da se djeca prije cijepljenja, čak i na eksplicitan zahtjev roditelja, ne podvrgavaju nikakvim testiranjima kojima bi se ustanovila eventualna preosjetljivost na neki od elemenata sastava cjepiva i/ili kojima bi se eventualno utvrdila potencijalna kontraindikacija, iako ono u uputama o lijeku stoji kao preduvjet cijepljenju.

Spomenuti primjeri ukazuju na lošu komunikaciju roditelja i predstavnika sustava, liječnika i čine puno razumljivijom potrebu amaterskog istraživanja katkada kontradiktornih medicinskih podataka. Takva praksa, kao i potreba jedne grupacije ljudi da objasni "pravu istinu" drugoj i obrnuto, pojašnjava i zamjetan broj različitih grupacija (od facebook grupa do udruga) koje se amaterski bave istraživanjem i interpretacijom stručnih i znanstvenih medicinskih podataka. Naime, kada je upravo na internetu, a ne u liječničkoj ordinaciji moguće pronaći upute o lijeku za svako cjepivo, postaje razumljivije spomenuto posezanje za informacijama na googleu, u situaciji kada je potpuno nejasno zašto bi se roditeljima, kao jedinima odgovornima za vlastitu djecu, uskraćivale informacije o cjepivima. Praksa izostavljanja informiranog pristanka za medicinski postupak ostaje daleko od najviših stručnih, etičkih i pravnih standarda. Naime, jedan od temeljnih principa moderne medicine etička je i legalna doktrina autonomije pacijenta i njegova prava na samoodređenje, a uskraćivanje informacija pacijentu smatra se oblikom stare paternalističke prakse koja

\footnotetext{
${ }^{21}$ Donekle, jer neki podaci nisu dostupni ili dovoljno transparentni. Primjerice, za potrebe izrade svoga doktorata, Mateja Černič nije uspjela dobiti na uvid dokumentaciju temeljem koje neko cjepivo dobiva dozvolu za stavljanje u promet. Glavna slovenska agencija za lijekove navela je da ti podaci predstavljaju poslovnu tajnu i izjavila da "ne mogu dati podatke o sastavu cjepiva, jer bi tada ljudi masovno izbjegavali cijepljenje i dogodio bi se odlazak prodavača i proizvođača cjepiva s tržišta” (Černič 2012: naslovnica). Također, internistica Lidija Gajski podnijela je u travnju 2012. godine Agenciji za lijekove i medicinske proizvode Zahtjev za pristup informacijama o tome temeljem kojih su kliničkih istraživanja donesene odluke o djelotvornosti i sigurnosti (a slijedom toga odobrenje za primjenu), i u kojim indikacijama i populacijama, za cjepivo protiv ospica, zaušnjaka i rubeole, za cjepivo protiv tetanusa i za cjepivo protiv sezonske gripe. Osim načelnog, konkretan odgovor na postavljeno pitanje nije uslijedio (usp. Dopisivanje Gajski HALMED).
} 
uništava odnos dviju strana, a povrh toga može biti izvorom loše prakse, navođenja, nemara i propusta (Domaradzki 2015: 158).

Donedavno je u slučaju odbijanja ili odgađanja cjepiva roditeljima na potpis nuđena Izjava o odbijanju cijepljenja koja je nekoliko godina kolala po medicinskim ustanovama (od rodilišta do pedijatrija), a služila je i kao sredstvo zastrašivanja i ucjene. Potpisivanjem spomenute izjave, roditelji su osiguravali necijepljenje djece, ali i prijavu za zanemarivanje djeteta nadležnim institucijama (od socijalne službe, policije do suda). ${ }^{22} \mathrm{Na}$ "Simpoziju o cijepljenju” održanom 14. ožujka 2015. godine u Zagrebu izjavljeno je da je sporna Izjava povučena iz uporabe jer je utvrđeno da nema pravnog uporišta (v. Kaić 2015: 52), a za protupravne radnje zastrašivanja, ucjenjivanja i progona roditelja, nitko nije odgovarao.

\section{NUSPOJAVE, RIZICI I PRAVNA REGULATIVA}

Osim u uputama o lijeku, i u Programu obaveznog cijepljenja odnosno Kalendaru cijepljenja kao opće kontraindikacije za sve imunizacije navedene su, između ostalih, teže nepoželjne reakcije pri prethodnoj dozi cjepiva. Međutim, prema iskazima mojih ispitanika, vrlo je teško dobiti dokumentaciju koja bi registrirala nepoželjne reakcije i poslužila kao dokaz za kontraindikaciju prilikom sljedećeg cijepljenja ili docjepljivanja. Također, liječnici, osim blagog otoka na mjestu uboda i povišene tjelesne temperature, nuspojave gotovo ne prepoznaju ili ih ne dovode u vezu s cjepivom pa se u praksi često događa da se teže (ili blaže) reakcije zapravo ignoriraju ili se, još češće, proglašavaju pukom koincidencijom i opet ignoriraju te se ne prijavljuju. ${ }^{23}$ Takva se praksa nadovezuje na izostanak informiranog

22 Temeljem Izjave liječnici roditelje prijavljuju Službi za epidemiologiju Hrvatskog zavoda za javno zdravstvo, koja prijavu prosljeđuje Sanitarnoj inspekciji Ministarstva zdravlja, a ona Centru za socijalnu skrb. Sanitarna inspekcija izdaje prekršajni nalog protiv roditelja uz obvezu plaćanja zakonske kazne za necijepljenje djeteta (čl. 77. Zakona o zaštiti pučanstva od zaraznih bolesti). Centar za socijalnu skrb radi "sumnje u zanemarivanje djeteta" (prema odredbama Obiteljskog zakona) poziva roditelje na razgovor(e) kod socijalnog radnika i/ili psihologa ili najavljuje njihov dolazak na razgovor u dom roditelja.

${ }^{23}$ U izvještaju već spomenutog Simpozija o cijepljenju održanog 2015. godine u organizaciji Hrvatskog zavoda za javno zdravstvo, Hrvatskog društva za preventivnu i socijalnu pedijatriju HLZ te Hrvatskog epidemiološkog društva HLZ navodi se, u izlaganju dr. Vesne Višekruna Vučina, da "broj prijava nuspojava cjepiva ne ovisi isključivo o reaktogenosti cjepiva, već u većoj mjeri o pristupu (aktivnom ili pasivnom) praćenju nuspojava i spremnosti zdravstvenih djelatnika da prijave uočenu nuspojavu", a "osnovna svrha praćenja nuspojava cijepljenja je uočiti signal: eventualno javljanje neobičnih nuspojava ili grupiranja nuspojava, radi poduzimanja odgovarajućih mjera. Najčešće signal potakne na dodatno istraživanje, radi rasvjetljavanja događaja, a na temelju dodatnog istraživanja se iznova procjenjuje odnos koristi i rizika za dotično cjepivo" (usp. Izvještaj). Nadalje, na stručnom skupu "Cijepljenjem protiv pneumokoka, prevencijom do zdravijeg djetinjstva”, u organizaciji Nastavnog zavoda za javno zdravstvo "Dr. Andrija Štampar” u suradnji s Hrvatskim pedijatrijskim društvom, održanom 8. veljače 2018. godine, liječnica iz publike navodi podatke za 2016. godinu o tek 142 prijavljene nuspojave te ističe da je to od ukupno primljenih doza tek 0, $02 \%$, znatno manje nego što je naveo proizvođač, odnosno statistički gotovo nemoguće. S obzirom na to da ti podaci govore o omjerima štete i koristi, postavlja pitanje: "Kako na temelju takvih podataka možete odgovorno tvrditi da je šteta tako mala?" Voditelj Nacionalnog programa cijepljenja priznaje da ne postoji sustavno postmarketinško praćenje sigurnosti cjepiva te smatra da to nije niti potrebno jer bi tada godišnje bilo 50000 do 60000 prijavljenih blagih nuspojava (v. Klokanica). Voditelj odsjeka za farmakovigilanciju u HALMED-u, dr. med. Darko 
pristanka, jer niti roditelji, a dijelom niti liječnici, ukoliko ne čitaju upute o lijeku, ne mogu znati što još očekivati osim navedenih blagih reakcija. Ostaje dojam da nuspojava među djecom gotovo i nema, a pojedine roditelje posebno zabrinjava da se čak niti one jasno navedene u uputi o lijeku ne priznaju nuspojavama. ${ }^{24}$

Ja se time nikad nisam bavila, niti cjepivima, niti politikom, ja sam uredno po kalendaru dovodila dijete na cijepljenje dok nije postalo evidentno da je djetetu sve gore i gore i da ima sve više i više nuspojava. Za nikakve upute o lijeku nisam znala, niti da mogu koga to tražiti, pitati, a ispada da ne smiješ ni danas. Tek sam poslije, kad sam konačno pročitala upute, vidjela da su sve nuspojave moga djeteta crno na bijelo navedene u uputama, samo kao jedno na valjda tisuću... a vidiš oko tebe sve puno klinaca s tim navedenim boleštinama, je, je jedno na milijun, kak ne... pa sam obavijestila pedijatra o tome, a ovaj veli: "Joooj, dajte, mama, kakvo cjepivo, cjepiva su vam danas sigurnija nego ikad." (E. P.)

Slična iskustva bilježe se i na društvenim mrežama premda su liječnici dužni prijaviti svaku sumnju na nuspojavu. ${ }^{25}$ Pod pretpostavkom da je riječ o anegdotalnim slučajevima koji ništa ne dokazuju ili da subjektivnost roditelja ometa ispravnu interpretaciju i zaključivanje, mnogi se roditelji suočavaju s nerazumijevanjem liječnika od kojega traže pomoć ili objašnjenje.

Znam svoje dijete, gledam ga svaki dan, pratiš svaki pomak, svaku promjenu, napredak i onda nakon cjepiva se dijete promijeni, razboli, a oni uporno pričaju nije od cjepiva, pa pitaš od čega je, ne znaju, ali od cjepiva sigurno nije. (D. Š.)

Korelacija ne mora biti uzročno-posljedična, ali može, i stoga kritičari cijepljenja smatraju da je nuspojave potrebno evidentirati jer, kako stoji u uputama o lijeku, "prijavljivanjem nuspojava možete pridonijeti u procjeni sigurnosti ovog lijeka”. Nesustavno i nekontrolirano prijavljivanje nuspojava na koje ukazuju kritičari sustava procjepljivanja dovodi u pitanje pouzdanost i realnost službenih statističkih podataka o pojavnosti nuspojava. Također, u

Krnić, izjavljuje na Stručnom forumu o cijepljenju održanom 30. listopada 2018. godine u hotelu Westin u Zagrebu da je prijavljivanje nuspojava "neživotno", "besmisleno" i "mrtvo slovo na papiru”. Također, prof. dr. Željko Poljak, alergolog i klinički imunolog, u Liječničkim novinama ukazuje na mali broj prijavljenih nuspojava te navodi i vlastito iskustvo: "encefalitis moje kćeri nije u bolnici registriran kao posljedica cijepljenja jer se, navodno, može objasniti i koincidencijom (!?)” (2011: 39).

Nedavno je pokrenuta i spomenuta facebook stranica koja osigurava prostor ismijanim i/ili ignoriranim i drugim svjedočanstvima roditelja, simboličnog naziva Glupače, a kao objašnjenje zašto baš tog naziva, navodi se: "jer smo sve glupače u njihovim očima”, "jer smo vjerovale slijepo u struku”, "jer medicinska struka smatra da nas ne treba informirati, da nas ne treba pitati za dozvolu", "gledaju nas kao glupače ako vopće dovedemo u pitanje cjepivo i rizik koje ono nosi".

${ }^{24}$ Mnogi roditelji nakon cijepljenja svjedoče poremećajima krvi i limfnog sustava, kože i potkožnog tkiva, poremećajima imunološkog i živčanog sustava. Posebno su učestale primjerice infekcije gornjih dišnih putova, infekcije srednjeg uha, bronhitisi, dermatitisi, alergije. Sve redom navedene nuspojave u pojedinim, ili u većini uputa o lijeku.

${ }^{25}$ Obaveza prijavljivanja sumnje na nuspojavu/e regulirana je Zakonom o lijekovima (NN 76/2013., čl. 145.) i Pravilnikom o farmakovigilanciji (NN 83/13.). Zakon o lijekovima (čl. 229.) predviđa i novčanu kaznu u iznosu od 30.000,00 do 50.000,00 kuna za prekršaj neprijavljivanja nuspojava. Međutim, zakonodavac je propustio propisati nadležno tijelo i postupanje u situacijama kada liječnici ne prijave nuspojavu ili sumnju na nuspojavu te takva prijava nije zabilježena. 
slučaju stradanja djeteta od cjepiva u Hrvatskoj ne postoji odštetni fond (za djecu), ${ }^{26}$ niti su kod nas, koliko mi je poznato, zabilježene tužbe protiv proizvođača cjepiva. ${ }^{27} \mathrm{U}$ svakom slučaju, pa i u slučaju neželjenih posljedica cijepljenja odgovornost snose isključivo roditelji/skrbnici.

Istovremeno, mogućnosti pojavljivanja nuspojava zapravo nitko ne negira, a zagovaratelji cijepljenja istodobno izjavljuju da su cjepiva sigurna kao i da nuspojave postoje. Pravobraniteljica za djecu Ivana Milas Klarić izjavila je da "postoje rizici od nuspojava, ali nuspojave može izazvati bilo koji medicinski preparat, pa čak i najobičniji aspirin" (s. n. 2014). Razlika je jedino u tome što aspirin, kao i svaki drugi lijek osim cjepiva, ima priloženu uputu o lijeku, lijek je za oboljele, a ne zdrave te ne podliježe zakonskoj obavezi konzumiranja. Također, Hrvatska liječnička komora u suradnji s Hrvatskim zavodom za javno zdravstvo na svojim je stranicama donijela "stručni osvrt na zablude o cijepljenju" gdje, između ostalog, stoji pitanje: "Tko može garantirati da cijepljeno dijete neće biti jedno od onih koje će imati nuspojave?", iza kojeg slijedi odgovor: "Nitko ne može garantirati da naše dijete neće biti jedno od onih koje će imati nuspojave nakon cijepljenja. To je rizik koji svjesno preuzimamo znajući da su dobrobiti cijepljenja znatno veće u usporedbi na potencijalne rizike". Rasprave oko cjepiva mogu se jednim dijelom sažeti upravo na ovom pitanju. Kritičari postojećeg sustava procjepljivanja u pravilu nisu uvjereni da je dobrobit veća od rizika i (taj) rizik ne žele dobrovoljno preuzeti. Smatraju to kompromitacijom dječjeg zdravlja te zadiranjem u prava djeteta i njegov tjelesni integritet.

Upravo zbog represije nad tjelesnim integritetom i osobnim slobodama pojedinaca cijepljenje je na razini preporuke u brojnim zapadnoeuropskim državama. ${ }^{28}$ Ta činjenica ukazuje da konsenzusa po tom pitanju nema, a obaveza stoji kao politička odluka. ${ }^{29}$ lako

${ }^{26}$ Istovremeno, iako ne postoji odštetni fond za djecu stradalu od cjepiva kao u drugim zemljama u kojima se primjenjuju ta ista cjepiva, odšteta je pravno regulirana kada od cijepljenja nastradaju životinje. Na službenim stranicama Ministarstva poljoprivrede stoji obavijest iz 2017. godine o isplati 19 milijuna kuna naknade proizvođačima mlijeka zbog pada mliječnosti kod životinja koje su cijepljene protiv bolesti kvrgave kože (https://poljoprivreda.gov.hr/vijesti/krenula-isplata-19-7-milijuna-kuna-proizvodjacima-mlijeka/653).

${ }_{27}$ Američki je kongres, primjerice, u doba Ronalda Wilsona Reagana zakonom National Childhood Vaccine Injury Act oslobodio farmaceutske kuće mogućnosti tužbe, ali istodobno omogućio i stvaranje nacionalnog kompenzacijskog fonda za žrtve nuspojava cjepiva (usp. npr. The National Childhood Vaccine Injury Act of 1986 i Škaričić 2017b). Osiguran pravni imunitet farmacijske industrije u slučaju nuspojava povod je brojnim sumnjama u “dobronamjernost" proizvođača, odnosno njegovu "brigu za kolektivno zdravlje”.

${ }^{28} \mathrm{Na}$ službenim stranicama Europskog centra za kontrolu i prevenciju bolesti (European Centre for Disease Prevention and Control) moguće je iščitati kalendare cijepljenja svih zemalja Europske unije. Navedene države s uglavnom obaveznim programom su: Bugarska, Češka, Francuska, Mađarska, Italija, Latvija, Poljska, Slovačka, Slovenija i Hrvatska. U Belgiji je obavezno cijepljenje samo protiv poliomijelitisa, a države u kojima je cijepljenje samo preporučeno su: Austrija, Cipar, Danska, Estonija, Finska, Njemačka, Grčka, Island, Irska, Lihtenštajn, Litva, Luksemburg, Malta, Nizozemska, Norveška, Portugal, Rumunjska, Španjolska, Švedska i Ujedinjeno Kraljevstvo (usp. European Centre for Disease Prevention and Control).

${ }^{29}$ Osim različitih kalendara cijepljenja, o izostanku konsenzusa govore različite interpretacije sponzoriranih i neovisnih znanstvenih istraživanja, a dijelom i selektivne vijesti. Primjerice, paralelno s donošenjem hrvatske Deklaracije o važnosti cijepljenja, koju je Hrvatska liječnička komora pokrenula u suradnji s Hrvatskim zavodom za javno zdravstvo i Školom narodnog zdravlja "Dr. Andrija Štampar”, hrvatski mediji propuštaju izvještavati o zbivanjima "druge strane priče” u svijetu ili bližoj okolici. Tako su u lipnju 2017. godine širom Italije organizirani masovni prosvjedi protiv uvođenja mandatornog cijepljenja, o kojima u hrvatskim 
u medicini svaki terapijski, dijagnostički ili preventivni postupak preporučuju liječnici, a na pacijentu je odluka hoće li preporuku prihvatiti, u slučaju cijepljenja u Hrvatskoj je propisana i obaveza i sankcija za njezino nepoštivanje. Pritom, argumenti zagovornika cijepljenja fokusirani su na samo jedan zakon, onaj o zaštiti pučanstva od zaraznih bolesti (NN 79/2007 čl. 40.), ali ne i na niz odredbi drugih zakona poput (već spomenutih) Zakona o zdravstvenoj zaštiti, ${ }^{30}$ Zakona o zaštiti prava pacijenata, ${ }^{31}$ pa čak i Kaznenog zakona, ${ }^{32}$ koji s prvospomenutim nisu u suglasju. I brojni međunarodni ugovori koji čine dio unutarnjega pravnog poretka Republike Hrvatske u koliziji su sa Zakonom o zaštiti pučanstva od zaraznih bolesti. Svakom neželjenom medicinskom intervencijom krše se odredbe, primjerice, Povelje Europske unije o temeljnim pravima, ${ }^{33}$ Konvencije o zaštiti ljudskih prava i dostojanstva ljudskih bića glede primjene biologije i medicine, Konvencija o ljudskim pravima i biomedicini Europskog vijeća, ${ }^{34}$ pa čak i Nürnberškog kodeksa. ${ }^{35}$ Stoga, ako roditelj od liječnika traži potpunu obavijest o cjepivu te utvrđivanje potencijalne preosjetljivosti djeteta na sastav cjepiva prije cijepljenja (kao preduvjet cijepljenju), može se tumačiti da roditelj time, u skladu sa zakonskim odredbama, izvršava svoju roditeljsku dužnost kao jedini (pravno i praktično) odgovoran za dijete. Roditelji koji inzistiraju na informacijama riskiraju prekršajnu prijavu jer se njihovi zahtjevi u praksi, kako navode moji sugovornici, često interpretiraju kao odbijanje cijepljenja.

medijima nije bilo vijesti. Mediji su donijeli tek informaciju da je cijepljenje i u Italiji postalo obavezno. Gotovo istovremeno, švedski parlament Riksdag donio je u svibnju 2017. godine odluku o odbijanju sedam prijedloga zakona vezanih za javno zdravlje, među kojima i prijedlog za uvođenje obaveze cijepljenja. Međunarodna neprofitna organizacija koja se zalaže za kontrolu svih mjera koje utječu na zdravlje građana, National Health Federation Sweden, u svom je pismu Parlamentu ukazala na argumente zbog kojih bi se uvođenjem obaveze cijepljenja kršila temeljna ljudska prava švedskih građana. U pismu se, između ostalog, navodi neutemeljenost prijedloga za uvođenje obaveze cijepljenja u pozitivnim propisima i međunarodnim konvencijama: "u suprotnosti je s Nürnberškim kodeksom jer cijepljenje nema dovoljno čvrste dokaze o učinkovitosti budući da nije napravljena pouzdana studija između cijepljene i necijepljene populacije, stoga se današnje masovno cijepljenje može smatrati velikim eksperimentom; iz istog razloga u suprotnosti je s Helsinškom deklaracijom (masovni eksperiment) [...] Svi građani Švedske protive se nasilnoj intervenciji nad tijelom. Svatko ima pravo odabrati hoće li se izložiti potencijalno opasnim tvarima ili neće” (usp. Riksdagen 2017).

30 Svatko ima pravo odbiti bilo koju medicinsku intervenciju, osim kad bi odbijanjem ugrozio zdravlje drugih (NN 150/2008 čl. 22. točka 6.).

${ }^{31}$ U članku 6. stoji: "Pravo na suodlučivanje pacijenta obuhvaća pravo pacijenta na obaviještenost i pravo na prihvaćanje ili odbijanje pojedinoga dijagnostičkog, odnosno terapijskog postupka”, a u članku 16. se isto još jednom potvrđuje: "Pacijent ima pravo prihvatiti ili odbiti pojedini dijagnostički, odnosno terapijski postupak, osim u slučaju neodgodive medicinske intervencije čije bi nepoduzimanje ugrozilo život i zdravlje pacijenta ili izazvalo trajna oštećenja njegovoga zdravlja" (NN 169/04, 37/08).

32 Kazneni zakon predviđa kaznu za liječenje bez pismenog pristanka (NN 110/1997 čl. 241.).

33 "Svatko ima pravo na poštovanje svog tjelesnog i duhovnog integriteta"; "U području medicine i biologije osobito se mora poštovati sljedeće: slobodni pristanak osobe o kojoj je riječ, na temelju njezine obaviještenosti i u skladu s postupcima utvrđenim zakonom" (v. Povelja čl. 3.).

34 "Interesi i dobrobit ljudskog bića imaju prevagu nad samim interesom društva i znanosti" (čl. 2.), "zahvat koji se odnosi na zdravlje može se izvršiti samo nakon što je osoba koje se zahvat tiče dala slobodan pristanak i pristanak na temelju poznavanja činjenica za njega. Toj se osobi prethodno daju odgovarajuće informacije o svrsi i prirodi zahvata, kao i o njegovim posljedicama i rizicima. Osoba može slobodno i u bilo koje vrijeme povući svoj pristanak" (v. Konvencija čl. 5.).

35 “Pristanak ljudskog subjekta je apsolutno nužan” (v. Ethical codes). 
Fokusiranost argumenata gotovo isključivo na jedan zakon i ignoriranje ostalih navedenih omogućuje progon samo jednih (onih koji cijepljenje iz različitih razloga izbjegavaju ili odgađaju) i potpuno izuzimanje drugih (onih koji represiju nameću i provode) od njihovih obaveza i odgovornosti. Zamjetni su ovdje uveličani grijesi pojedinaca i umanjeni ili u potpunosti tolerirani grijesi moćnika, odnosno politike i ekonomski moćnih proizvođača, distributera cjepiva i sl. Primjerice, u slučaju ne tako davne afere cjepiva protiv navodne pandemijske gripe, o kojoj je pisala istraživačka novinarka Nataša Škaričić, nitko nije odgovarao iako je, prema ocjeni Wolfgang Wodarga, predsjedatelja Odbora za zdravstvo Vijeća Europe, Svjetska zdravstvena organizacija s proizvođačima cjepiva sudjelovala u jednom od "najvećih javnozdravstvenih skandala u povijesti čovječanstva" (Škaričić 2014; više o recentnim propustima farmaceutske industrije usp. i 2017a).

\section{ČIJA SU NADLEŽNOST ODLUKE O PROCJEPLJIVANJU DJECE?}

Ustavni sud je 2014. godine ocijenio da samostalna odluka roditelja hoće li cijepiti svoju djecu nije njihovo ustavno pravo jer je pravo djeteta na zdravlje jače od prava roditelja na izbor, uz obrazloženje da je to prvenstveno medicinsko pitanje. Razvidno je da se Ustavni sud, osim što je pritom zanemario postojeći, već spomenuti Zakon o zaštiti prava pacijenata iz vlastitog (pravnog) područja, ${ }^{36}$ u ovom slučaju odrekao vlastite ingerencije odlučivanja o ljudskim pravima dodijelivši cijelu problematiku isključivo medicinskom području. Isto je učinio i Ured pravobraniteljice za djecu. S druge, pak, medicinske strane, vodeći hrvatski epidemiolog, u javnosti eksponirani zagovornik cijepljenja Bernard Kaić pojašnjava: "treba li cijepljenje biti obavezno ili preporučeno sociološko je i pravno, a ne medicinsko pitanje" (Srdoč 2017). Također, Povjerenstvo za medicinsku etiku i deontologiju Hrvatskog liječničkog zbora 2012. godine ocijenilo je da prisilno cijepljenje nije u skladu s medicinskom etikom. ${ }^{37} \mathrm{~S}$ obzirom na kontradikciju između odluke Povjerenstva kao kompetentnog tijela medicinske struke i dominantnog stava iste struke o neophodnosti, učinkovitosti i sigurnosti cjepiva, ostavlja se prostor za opravdanu sumnju da službeni stav medicinske struke nije usuglašen. lako odluka Ustavnog suda, ocjena Povjerenstva za medicinsku etiku i deontologiju te izjava vodećeg epidemiologa nisu hijerarhijski usporedive, navedeno prebacivanje nadležnosti jednih i istovremeno posezanje za ingerencijama o odlukama za dječje zdravlje drugih, ostavlja sumnju u nadležne institucije za spomenuto pitanje te ukazuje na kompleksnost pitanja koje premašuje kompetencije samo jedne (medicinske) struke. Naime,

${ }^{36} \mathrm{U}$ članku 17. navedenog zakona stoji da suglasnost o medicinskim intervencijama za maloljetnog pacijenta potpisuje zakonski zastupnik, odnosno skrbnik pacijenta (NN 169/04).

37 Povjerenstvo je takvu odluku iznijelo u službenom odgovoru prof. dr. sc. Željku Poljaku u kojem je navedeno također da liječnik ima pravo odbiti prisilno cijepljenje pozivajući se na priziv savjesti. Pritom valja napomenuti da prisilno cijepljenje nije isto što i obavezno cijepljenje. Obaveza povlači sankciju za necijepljenje, a prisila bi bila, pojednostavljeno, cijepljenje bez pitanja i informiranog pristanka, koje je, u nekim slučajevima, i dalje dijelom hrvatske prakse. 
[a]ko roditeljski strah da će njegovo zdravo dijete, zbog moguće nuspojave, biti žrtva interesa društvene zajednice pretvorimo u univerzalnu moralnu dilemu, ona će glasiti “je li moralno žrtvovati jedno ljudsko biće zbog dobrobiti cijele zajednice”, a odgovor će prvenstveno ovisiti o tome koju etičku teoriju zastupate, a tek onda o medicinskim činjenicama. Ako se, unatoč tome, uporno nameće biomedicinski pogled na problem, a sasvim negiraju moralne i političke dileme u odlučivanju, mogu se očekivati mnogi racionalni i iracionalni otpori ovakvom redukcionističkom stavu. (Škaričić 2014)

Pitanja u nadležnosti medicinske struke i sama su prožeta brojnim kontroverzama. Nadležnosti medicinske struke pripada primjerice briga o adekvatnim znanstvenim istraživanjima koja bi nedvosmisleno potvrdila ili odbacila učinkovitost ili sigurnost cjepiva. Potrebna su, za svako pojedino cjepivo, ali i njihove kombinacije, dugoročna klinička istraživanja, temeljem kojih bi bilo moguće izračunati omjere koristi i štete. ${ }^{38}$ Posebno problematičnim kritičari cijepljenja ističu nepostojanje dugoročnih istraživanja. Razlog se dijelom može nazrijeti kroz izjavu kompromitiranog, ${ }^{39}$ ali i nadalje vodećeg autoriteta u svijetu cjepiva, američkog CDC-a (Centra za kontrolu i prevenciju bolesti): “Višegodišnje praćenje cijepljene djece i traženje dugoročnih zdravstvenih posljedica bi bilo nepraktično, a oduzimanje novih cjepiva djeci kojima bi ta cjepiva koristila za vrijeme izvođenja dugoročnih studija je neetično" (CDC, Parent's Guide to Childhood immunizations). Također, za razliku od svih drugih lijekova, ne ispituju se farmakokinetička svojstva cjepiva, iako se cjepiva klasificiraju kao lijek. ${ }^{40}$ Kritičari cijepljenja ukazuju i na izostanak neškodljivog placeba (primjerice, fiziološke otopine) $u$ većem dijelu kliničkih istraživanja nakon kojih se cjepivo proglašava učinkovitim i sigurnim te pušta na tržište. ${ }^{41}$

U kritičara cijepljenja u znatnoj je mjeri istaknuto i nepovjerenje u kontekst znanstvenih istraživanja, posebno interesnu sferu i spregu farmaceutskih kuća i medicine, ne nužno u samu znanost. Naime, u nadležnosti medicinske struke bilo bi, primjerice, i sastavljanje preporučenog kalendara cijepljenja. Međutim, nekoliko autora, osim stručno medicinskih kriterija, ukazuje i na utjecaj nemedicinskih kriterija koji, između ostalih, mogu biti "agresivna propaganda, pritisak interesnih skupina (lobija), anegdotalni događaji koji rezultiraju velikim pritiskom na Program, a u novije vrijeme cijena cjepiva i dostupnost/mogućnost

\footnotetext{
${ }^{38}$ Primjerice, sigurnost kombinacije cjepiva unutar kalendara cijepljenja nikada nije klinički potvrđena u Americi (Miller 2016: 47-49) niti kod nas.

39 Dokumentarni film Vaxxed: From Cover-Up to Catastrophe (2016), između ostalog, prikazuje kako su odgovorni u američkom CDC-u svjesno i namjerno uništili podatke o štetnosti MMR cjepiva. lako cenzuriran, pojedine web stranice povremeno omogućuju njegovo emitiranje.

${ }^{40}$ Farmakokinetika predstavlja proces kretanja lijeka u tijelu, od doziranja do eliminacije. Proces obuhvaća apsorpciju, distribuciju, metabolizam i ekstrakciju lijekova iz tijela (usp. npr. MSD priručnik dijagnostike i terapije) i bez takvih istraživanja nepoznato je kako pojedini sastojci djeluju na organizam i u organizmu. $U$ uputama o lijeku navodi se da farmakokinetička istraživanja nisu provedena ili da za cjepiva nisu relevantna.

${ }^{41}$ Primjerice, u uputama o lijeku kao dokumentu koji je rezultat znanstvenih istraživanja pojedinog cjepiva, u opisu kliničkih istraživanja, navode se često dvije skupine u kojima obje primaju neko cjepivo (najčešće uredno po kalendaru cijepljenja države u kojoj se istraživanje provodi), samo što jedna skupina usporedo prima i cjepivo koje se istražuje.
} 
nabave cjepiva” (Kaić i Višekruna Vučina 2016: 9).42 "Kako u kurativnoj medicini prije, tako sada u cijepljenju počinje dominirati novac i borba na tržištu. Pod stručnim i opravdanim, ali i pod neopravdanim ili lobističkim pritiscima se u manjoj ili većoj mjeri mijenja Program cijepljenja" (Milas, Smoljanović i Miškulin 2008). Primjer cjepiva koje je, unatoč protivljenju (medicinske) struke, kao politička odluka, uvedeno u Program obaveznog cijepljenja je cjepivo protiv hepatitisa B ${ }^{43}$ (usp. Zenić 2004; Milas, Smoljanović i Miškulin 2008; Kaić i Višekruna Vučina 2016: 9). Nije se, kako se navodi u Hrvatskom časopisu za javno zdravstvo,

pravodobno provelo ispitivanje o potrebi promjene kalendara cijepljenja, nego je izmjena učinjena preko noći. Na ovaj je način napravljen presedan koji će u budućnosti omogućiti svakome dovoljno upornom, snalažljivom i snažnom mijenjati po svojoj volji kalendar cijepljenja. [...] Promjenom kalendara cijepljenja sada se u pravilu cijepe djeca koja do adolescencije nisu u riziku od zaraze. Mislimo da se na ovaj način željelo opteretiti dijete s velikim brojem cjepiva u prvih nekoliko mjeseci života kao prvi korak u budućem pronalaženju rješenja. "Rješenje" je primjena polivalentnih i skupih cjepiva. Posljedice su višestruke. (Milas, Smoljanović i Miškulin 2008)

Ova se prognoza "rješenja" u potpunosti ostvarila. Danas su u kalendaru doista gotovo isključivo polivalentna cjepiva, ${ }^{44}$ a o eventualnim posljedicama se javno (još) ne progovara. Također, godine 2008. stručno je mišljenje da javnozdravstvene ustanove ne bi trebale sudjelovati u promoviranju cijepljenja protiv HPV virusa te da se cjepivo ne može preporučiti muškim osobama (Kaić, Gjenero-Margan i Nemeth-Blažić 2008), iako je današnja praksa dijametralno suprotna. Potom, u sastavljanju programa cijepljenja slijede se preporuke kompetentnih organizacija poput Svjetske zdravstvene organizacije WHO čija je preporuka ukidanje sustavnog BCG cjepiva, a prema izvještaju sa Simpozija o cijepljenju održanog 2015. godine, u izlaganju doc. prim. dr. sc. Anamarije Jurčev Savičević zaključeno je analizom epidemiološke situacije u Hrvatskoj i sustava prijavljivanja oboljelih od tuberkuloze "da se trebamo pripremiti za skoro ukidanje sustavnog BCG cijepljenja novorođenčadi, posebice identificiranjem rizičnih skupina kojima bi bilo usmjereno eventualno selektivno cijepljenje" (Izvještaj 2015). Pritom, u trogodišnjem Programu obaveznog cijepljenja u Republici Hrvatskoj (2019.- 2021.) i nadalje je predviđeno cijepljenje djece u rodilištima protiv tuberkuloze BCG cjepivom, bez potrebe tuberkulinskog testiranja prije cijepljenja do

\footnotetext{
${ }^{42}$ Nakon sumnje na nuspojavu koja je uslijedila kod njezinoga djeteta nakon cijepljenja dTpa-R (Reforco) tj. Refortrix cjepivom (usp. bilj. 11), u pisanoj komunikaciji s Ministarstvom zdravlja (MZ), Hrvatskim zavodom za javno zdravstvo (HZJZ), Agencijom za sigurnost lijekova (HALMED), Hrvatskom liječničkom komorom (HLK), Hrvatskim pedijatrijskim društvom i Hrvatskim liječničkim zborom, dr. med. Alma Demirović dolazi do podatka da se u postupku nabave cjepiva za potrebe provođenja nacionalnog programa cijepljenja pristupa i tzv. interventnom uvozu lijekova, pri kojemu mahom proizvođači, a ne struka, uvjetuju čime se program provodi. Kao primjer takve prakse navodi dTpa-R (Reforco) tj. Refortrix cjepivo, koje nije odobreno nigdje u EU, iako na stranicama HALMED-a i HLK-a stoji podatak da se u RH koriste samo cjepiva odobrena u EU (usp. Borić 2018).

${ }^{43}$ U Republici Hrvatskoj se od 1999. godine, prema Programu obaveznih cijepljenja, protiv hepatitisa B cijepe djeca u šestom razredu osnovne škole, a od 2007. do 2015. godine cijepila se i sva novorođenčad (Milas, Smoljanović i Miškulin 2008).

${ }^{44}$ Osim cjepiva protiv dječje paralize koje je i monovalentno, to su cjepiva 6u1, 5u1, 3u1, $2 u 1$.
} 
navršene prve godine života. Nadalje, Milas, Smoljanović i Miškulin 2008. godine upozoravaju koliko bi loša bila odluka uvođenje cjepiva protiv pneumokokne infekcije u Program cijepljenja za koje u Hrvatskoj "postoji stalni pritisak", a kao konačna odluka mainstream struke, njegovo je uvođenje u obavezan program s početkom 2019. godine. ${ }^{45}$

Proizlazi stoga da, iako se drugačije prezentira, medicinski argumenti nisu jedini, niti su jedinstveni kada se izrađuje kalendar cijepljenja, a kao takvi svakako ne bi trebali biti jedini (vidi o odluci Ustavnog suda gore u tekstu) kada se nameće zakonska obaveza.

\section{KOLEKTIVNI IMUNITET I ALTRUIZAM}

Najčešći argument i teorija na kojoj zapravo počiva zakonska obaveza tzv. je imunitet krda ili kolektivni imunitet, odnosno ideja da je važna visoka procijepljenost da bi se kolektiv (ili nacija) čuvao od epidemija bolesti i zato je, između ostalog, potrebno da se jedni cijepe i zbog drugih (onih premladih ili imunokompromitiranih koji cjepiva ne smiju primiti). ${ }^{46}$ Stoga se, osim zakonske obaveze, apelira i na altruizam. ${ }^{47}$

U publikaciji Hrvatskog zavoda za javno zdravstvo o nuspojavama cjepiva (za 2014. i 2015.) stoji da su u obaveznom programu cijepljenja u te dvije godine postignuti zapravo visoki cjepni obuhvati, uglavnom preko 95\% za djecu, dok je cjepni obuhvat šezdesetogodišnjaka tek 41,6\%. Također, godine 2016. u Narodnom zdravstvenom listu, primjerice, spominje se izuzetno mala procijepljenost osoba u dobi iznad šezdeset godina. Iznosi svega 29,4\% (Gastović Bebić 2016: 15). Taj podatak u javnosti nije izazvao strah ili paniku, nisam o tome zabilježila niti jedan novinski napis te, koliko mi je poznato, nisu zabilježene sankcije iako se radi o istom, obaveznom programu, samo su u ovom slučaju oni koji su trebali primiti cjepivo - odrasli, a ne djeca.

Dijete koje nije cijepljeno ne može u vrtićc8 i, iako zdravo, predstavlja se opasnim za zdravlje druge djece. Pritom, djelatnici vrtića, djelatnici prosvjetnih ustanova, djelatnici u

${ }^{45}$ Milas, Smoljanović, Miškulin (2008) navode primjere gdje su se nakon prividnih uspjeha cijepljenja protiv pojedinih bolesti poput pneumokokne infekcije ili hepatitisa B te iste bolesti vratile $u$ izmijenjenom obliku (uz prevladavajući virus drugog tipa koji cjepivo ne sadrži). Navode i iskustvo s medicinskog skupa na kojem se stavove istraživača koji ukazuje na takve pojavnosti ignorira.

${ }^{46}$ Pritom, nisu sva cjepiva kojima se djeca cijepe osobna i kolektivna zaštita, nego samo osobna.

${ }^{47} \mathrm{Kada}$, primjerice, oni koji snose teret vakcinacije, odnosno njezine rizike nisu isti pojedinci koji ubiru njezine benefite (zaštitu od pojedinih bolesti), strategija za postizanje optimalnog zahvaćanja vakcinacijom postaje obavezna vakcinacija, a jedan od načina za izbjegavanje obavezne vakcinacije poticanje je altruistične vakcinacije, one gdje će se pojedinci dobrovoljno cijepiti za promociju zajedničkog dobra (usp. Vietri i dr. 2012: 455).

48 Temeljem Programa zdravstvene zaštite djece, higijene i pravilne prehrane djece u dječjim vrtićima (čl. 3. NN 105/2002) pohađanje vrtića uvjetovano je obaveznim cijepljenjem. Njime se zdravoj i necijepljenoj djeci, bez dokaza o kliconoštvu ili zarazi, priječi boravak ili brani upis u vrtić što se može promatrati i kao oblik diskriminacije. Također, propisani je obrazac koji pedijatar ispunjava pri upisu djeteta u dječji vrtić dvosmislen s obzirom na to da postavlja dva potencijalno kontradiktorna pitanja: "Je li dijete primilo sva propisana cijepljenja?” i “Je li dijete sposobno za pohađanje vrtića?". 
trgovinama, dječjim igraonicama ili drugim javnim mjestima nisu dužni, ako su i cijepljeni (ovisno o godištu), ${ }^{49}$ docjepljivati se cjepivima protiv bolesti koje prijete javnom zdravlju. Spomenuto je (i stoji u uputama o lijeku) da cjepivo neće osigurati zaštitu svakom cijepljenom niti njegova primjena garantira doživotnu zaštitu. Također, zabilježen je slučaj da je upravo cjepivo uzrokovalo bolest protiv koje se cijepi. ${ }^{50} \mathrm{Iz}$ te računice proizlazi da bi necijepljena djeca i, primjerice, odgajateljica u vrtiću mogli biti gotovo istog cijepnog statusa, s jedinom razlikom da dijete predstavlja opasnost za drugu djecu u vrtiću (i šire) i stoga će njegovi roditelji potencijalno biti sankcionirani, a djetetu će biti onemogućeno pohađanje vrtića, dok odgajateljica ne predstavlja opasnost za tu istu djecu u vrtiću (i šire) te ne snosi sankcije jer ne podliježe zakonskoj obavezi.

Ako se slabo cijepe odrasli koji su po Zakonu o zaštiti pučanstva od zaraznih bolesti i kalendaru cijepljenja to dužni činiti, ako se ne docjepljuju odrasli koji po zakonu to nisu dužni, ali potencijalno više nisu zaštićeni, ako postoji mogućnost da se upravo od cjepiva može razboljeti od bolesti protiv kojih se cijepi, ako cjepiva ne štite neograničeno i ako ne štite svakoga tko se cijepi kao što je navedeno u svakoj uputi o lijeku, postoji li uopće kolektivni imunitet i zašto bi on trebao pasti isključivo na leđa vrlo male djece. Naime, proizlazi da je nepoznato koliko ljudi ima ili nema ostvaren imunitet za bolesti protiv kojih se cijepi. Kada bi se razjasnila ova zagonetka, preostao bi (ne nužno jedini) problem granica, koje virusi ne poznaju pa mogu useliti i iz zemalja u kojima postoji sloboda izbora ili niža procijepljenost. Za javno zdravlje, ideju kolektivnog imuniteta potrebno je demistificirati te svakako jasnije objasniti i opravdati.

Također, pozivanje na altruizam u slučaju cijepljenja nema jedinstveno značenje za sve one na koje se apelira i stoga ne može biti jedinstvenog učinka. Onima kojima postavke cijepljenja nisu dovoljno uvjerljive (posebno imunitet kolektiva), altruizam nema isto značenje kao i onima drugačijega razmišljanja pa se ideja altruizma u tom slučaju lako može zamijeniti ili čak poistovjetiti s idejom žrtvovanja. U tom slučaju, postaje nejasno čemu žrtvovanje ako iz njega ne proizlazi korist. Naime, za razliku od zagovaratelja cijepljenja koji smatraju da sastav cjepiva ne narušava imunološki sustav djece, kritičari cijepljenja, posebno roditelji s iskustvom narušenog zdravlja njihova djeteta nakon cijepljenja, ukazuju na narušavanje (cjelokupnog) imuniteta djeteta i podložnost stvaranju bolesti upravo zbog i nakon cijepljenja, pa iz takvog razumijevanja ne proizlazi svijest o važnosti očuvanja kolektivnog zdravlja. ${ }^{51}$

Oni misle da smo sebični. Sebični bi bili kada bismo, kao oni, doista vjerovali u taj fantomski imunitet krda pa se ne bi cijepili i onda bi se mi švercali. Oni to isključivo

\footnotetext{
${ }^{49}$ Cjepivo protiv ospica, primjerice, uvedeno je u Kalendar 1968. godine.

50 Stručnjaci iz Zavoda za javno zdravstvo opisali su 2010. godine slučaj četrnaestomjesečnog djeteta koje se razboljelo upravo radi cijepljenja, odnosno zarazilo virusom iz cjepiva protiv ospica, zaušnjaka i rubeole, a ne divljim (prirodnim) virusom (usp. Kaić i dr. 2010).

51 Primjerice, u samim uputama o nekim cjepivima navedeni su "poremećaji imunološkog sustava" kao što su "reakcije preosjetljivosti ili anafilaktički šok zbog preosjetljivosti na neku od komponenti cjepiva" (usp. cjepivo protiv poliomijelitisa, Imovax Polio).
} 
tako vide i ne odstupaju. Uzimaju da su postavke od kojih polazimo iste. A nisu. Ja mislim da oni ugrožavaju moje necijepljeno dijete živim virusima iz cjepiva. I kažu da je to nemoguće, da se virusi iz cjepiva ne prenose, a postoje živi ljudi koji svjedoče upravo takvom prijenosu, ali nisu bili dio istraživanja kad se provodilo, ovo postmarketinški nije dovoljno uvjerljivo jer sve odlazi na neželjene posljedice nakon cijepljenja i nikako zbog cijepljenja. A kako da laici dokazuju da je zbog cijepljenja, kad ni struka to ne želi uzeti u obzir i temeljem takvih brojnih svjedočanstava napraviti istraživanje. Oni misle da mi ugrožavamo imunokompromitirane, a mi mislimo da su mnogi od njih imunokompromitirani upravo zbog cjepiva. I tako unedogled. Jednostavno polazimo od različitih pretpostavki. S time da će oni reći da nema pretpostavki, da je sve to dokazana znanost, a nije. Možete naći znanstvene radove i argumente i za jedno i drugo polazište. I tako ukrug. (K. O.)

U nekih roditelja strah od mogućih neželjenih posljedica cijepljenja prednjači pred strahom od obolijevanja od pojedinih bolesti koje se cjepivom preveniraju. Ujedno, mnogi od njih ne smatraju da njihova djeca ugrožavaju drugu djecu s obzirom na to da su zdrava i nisu nosioci uzročnika (bolesti). Ideju zazivanja altruizma jedna je majka slikovito objasnila:

Sebična sam mater i sebi sam rodila dijete da bude zdravo i sretno, a ne da spašava svijet. O tome neka sam odlučuje kada odraste. Propagande gdje mame bolesne djece koja se ne mogu cijepiti placu i mole druge da cijepe svoju djecu su žalosne, jer ako znaš sto je bolesno dijete, kako možeš drugog roditelja tražiti da riskira sa svojim? (na facebook stranici Cijepljenje - pravo izbora)

Stoga, pri apeliranju na altruizam korisno bi bilo upoznati bojazni i strahove onih na koje se apelira s obzirom na to da jedinstvena strategija usmjerena podjednako na sve grupe jednostavno nije djelotvorna, a neujednačeno razumijevanje ideje altruizma te nedovoljno razjašnjena ideja kolektivnog imuniteta uvjetuju razna strahovanja te stvaraju nepovjerenje prema sustavu.

\section{DJEČJA PRAVA I ZDRAVLJE}

Spomenuta odluka Ustavnog suda da je pravo djeteta na zdravlje jače od prava roditelja na izbor uvodi novo značenje zdravlja i navodi na pitanje na koji način cijepljenje donosi ili osigurava zdravlje.

Vrlo široka i inkluzivna definicija zdravlja Svjetske zdravstvene organizacije (World Health Organization) da je zdravlje "stanje potpunog tjelesnog, duševnog i socijalnog blagostanja, a ne samo odsustvo bolesti i iznemoglosti”, medicini olakšava kontrolu nad složenim dimenzijama društvenog života (usp. Domaradzki 2013: 25). Zdravlje se, osim cijepljenjem, može osigurati i osiguranjem uvjeta za zdravlje kao što su pitka voda, nezagađen okoliš, adekvatno stanovanje, zaposlenost i dr., a prvenstveno higijenom. Naime, epidemiolozi Josip Milas i Mladen Smoljanović te predsjednica Katedre za obiteljsku medicinu i javno zdravstvo Medicinskog fakulteta Osijek Maja Miškulin navode da 
[p]oboljšanje higijensko-sanitarnih prilika na nekom području istodobno dovodi do nestanka bolesti koje su posljedica niske higijene. Puno je lakše osigurati novac za cijepljenje (makar i donacijama), nego uložiti napor, puno više novaca i vrijemena (sic) da se poprave higijensko-sanitarne prilike, a time i spriječi širenje ne samo jedne bolesti protiv koje postoji cjepivo, nego i puno više. (2008)

Briga za zdravlje u zapadnoj je medicini postala vječna borba protiv bolesti, bile one doista prisutne ili ne. "Umjesto da je se shvaća kao izoliran događaj koji ima početak i završetak, na bolest se počelo gledati kao na stalnog pratioca zdravlja, 'drugu stranu' zdravlja i uvijek prisutnu prijetnju" koju je potrebno neprestano suzbijati (Bauman 2001: 95 prema Svendsen 2010: 78). Norveški liječnik Ståle Fredriksen u središnje mjesto perspektive zdravlja stavlja pojam "peha". Razbolijeva li se neka osoba ili ne, ne ovisi samo o odabiru čije bi posljedice osoba sama ili njezina okolina mogla ili trebala predvidjeti nego o sreći i nesreći. On navodi tri tipa peha: (1) konstitucionalni peh, tj. s kakvim genima smo rođeni, imunitet itd., (2) peh povezan s okolnostima, tj. s kakvim se situacijama susrećemo, (3) konsekvencijalni peh, tj. nepredvidive posljedice naših odabira, a hoće li se osoba razboljeti, ovisi o svim faktorima te je iluzija vjerovati da se sve to može učiniti predmetom kontrole (Svendsen 2010: 84).

S pretpostavkom da pravo na zdravlje zapravo podrazumijeva pravo na dostupnu zdravstvenu uslugu, dr. med. Đula Rušinović Sunara u televizijskoj emisiji pita "kako je moguće od dostupne zdravstvene usluge nešto pretvoriti u obaveznu zdravstvenu uslugu" koja znači "dokidanje nečije slobode", odnosno kako je "od najvišeg ustavnog prava, slobode, došlo do ukidanja tog najvišeg ustavnog prava i tvrdnje da je to ustavno pravo" te kako je došlo do obavezivanja na cijepljenje jer će dijete "navodno ugroziti druge, a da ničim nije ugrozilo druge, nego se to samo pretpostavlja". ${ }^{2}$ Cijepljenje eventualno može smanjiti rizike od obolijevanja od pojedinih bolesti, pritom bez ikakvih garancija da je tome doista tako. Međutim, sporno je donosi li ono samo po sebi zdravlje.

Obaveza izlaganja rizičnom i tek preventivnom medicinskom postupku zdravog ili, još gore, bolesnog djeteta, koji može i ugroziti zdravlje, izjednačena je s pravom djeteta na zdravlje o kojemu njegovi roditelji ne bi trebali odlučivati. Obavezivanje na cijepljenje dovodi u pitanje temeljna ljudska prava, a posebno prava djece jer se temeljem "prava na zdravlje" roditelje obavezuje na rizičnu preventivnu intervenciju i narušava pravo na tjelesni integritet.

Zadiranje u tjelesni integritet djeteta olakšano je činjenicom da su djeca - djeca. Gill Valentine je upozorila da postoji predodžba da su djeca objekt zajedničke brige i to zato što se simbolički i stvarno povezuju s budućnosti. U predodžbenom svijetu zapadnoga kruga djeca su koncipirana kao nevina bića kojima je potrebna stalna zaštita (usp. 2010: 23). Reynolds, Nieuwenhuys i Hanson (2006) u dokumentima o dječjim pravima uočavaju niz proturječnosti među kojima se dječja prava na fizički i mentalni identitet i integritet spominju usporedo s njihovom tjelesnom i mentalnom nezrelošću i inferiornošću (prema

52 Emisija KLOPKA - "Obavezno cijepljenje - Da ili ne" emitirana 24. svibnja 2016. na SBTV (dostupno na: https://www.youtube.com/watch?v=zw1WGIs2EEY). 
Kopić i Korajac 2010: 46-50). Pri nastojanju eliminiranja svog rizika iz djetetova života, djeca se prikazuju kao objekti izloženi sve većim opasnostima jer su "najneviniji među nama”, a ujedno i "najbolji kandidati da budu žrtve” (Svendsen 2010: 67).

Također, u raspravama o dječjim pravima i pravima odraslih na izbor često se susreće konstatacija da djeca nisu vlasništvo roditelja. Naravno da djeca ne bi trebala biti vlasništvo roditelja, a još manje države i utoliko je pitanje vlasništva djece deplasirano, ali ostavlja mogućnost manipuliranja pravnim terminima. Primjerenije bi bilo raspravljati o odgovornosti. Nje su naime lišeni svi oni koji represiju podupiru i u njoj sudjeluju, dok potpunu odgovornost snose upravo oni nad kojima se represija čini.

Pritom, neki moji ispitanici izjasnili su se protiv prava na izbor jer im je neprihvatljiva odgovornost koju izbor donosi. Smatraju da roditelji nemaju dovoljno znanja da bi mogli odlučivati o cijepljenju djece te nisu zadovoljni idejom mogućnosti izbora iako su se neki od njih kritično izjasnili o politici cijepljenja. To potvrđuje heterogenost skupine kritične prema cijepljenju i govori o tome da je u najvećoj mjeri riječ o roditeljima koji strahuju za zdravlje djece i žele sustav javnoga zdravstva koji štiti interese svojih građana i u koji mogu imati puno povjerenje.

Ja jednostavno ne znam i u svakom slučaju, cijepila, ne cijepila, me strah. Ja ne mogu istraživati da bih odvagala. Ja to ne znam. A još je luđe da mi preostaje jedino da nekome vjerujem ili ne vjerujem. Pa, to je van svake pameti! Zamjeram i državi i vlasti i politici i liječnicima i svima koji su nedovoljno jasni i uvjerljivi po tom pitanju. (K. M.)

\section{UMJESTO ZAKLJUČKA}

Izostanak konsenzusa struke te nedovoljno jasne i transparentne informacije o cijepljenju i cjepivima (Bralić 2016: 156) ukazuju na potrebu mijenjanja pristupa, demistifikacije znanstvenih dokaza ${ }^{53}$ te, $u$ konačnici, sučeljavanja obiju strana u javnoj raspravi. ${ }^{54}$ Demokratsko sučeljavanje medicinskih stručnjaka osiguralo bi stručnu preporuku o pitanjima učinkovitosti, sigurnosti te omjerima štete i koristi. Međutim, obaveza cijepljenja nadilazi isključivo stručno medicinsku raspravu. Preventivni medicinski zahvat koji nosi rizike za zdravlje primatelja nametnut pod prijetnjom novčane kazne neminovno zadire u ljudska prava i slobode. Pitanja ljudskih prava i sloboda, etike te politički i ekonomski odnosi države i farmaceutske industrije svakako nalažu uključivanje šireg spektra (neovisnih) stručnjaka, osim isključivo medicinskih. Obje su rasprave trenutno onemogućene dok god je na snazi represivan zakon koji prijeti, zastrašuje i sankcionira ne samo roditelje nego medicinske i

\footnotetext{
${ }^{53}$ lako malo vjerojatno, posebno bi značajno bilo razdvajanje farmacije i medicinskih znanosti kako bi se dokinula interesna sfera koja nikako ne doprinosi niti neovisnim i objektivnim istraživanjima niti brizi za javno zdravlje.

${ }^{54}$ Nekoliko je stručnjakinja u javnim nastupanjima ukazivalo na potrebitost javne rasprave (primjerice internistica dr. sc. Lidija Gajski i novinarka Nataša Škaričić).
} 
druge stručnjake koji se, ukoliko kritički promišljaju postojeći režim cijepljenja, neće (javno) oglasiti i time potencijalno riskirati ugled i karijeru (usp. i bilj. 3). Ovdje upućujem na primjere iz istraživanja u kojima sugovornici svjedoče o tome kako su im upravo pedijatri ili drugi medicinski stručnjaci pobudili prve sumnje vezane za cjepiva, uputili prva upozorenja o njihovoj neučinkovitosti ili nesigurnosti te ih savjetovali da prestanu cijepiti dijete, a pritom iskazali i vlastiti strah.

Nakon nesvjestice djeteta nakon prethodnog cijepljenja, kad smo došli idući put na docjepljivanje, rekla nam je da idemo cijepiti u Klaićevu u kontroliranim uvjetima. Rekla je da ju je previše strah i da si ne želi priuštiti da joj dijete ostane na stolu. Bili smo čak malo ljuti što nas šalje naokolo i tako nas zastrašuje, i tek onda šok... pa, šta nam dijete može "ostati na stolu"? Ma, zaboravi, nikakvo cjepivo od onda nije primio. (I. G.)

Doktor u Klaićevoj nam je savjetovao da prestanemo cijepiti dijete ako želimo da ozdravi i da je sve to najvjerojatnije uzrokovano cjepivima. Pitali smo ga može li nam to napisati. Ne može, naravno. Rekao je da je to komplicirano i da nam ne bi svaki liječnik to savjetovao, ali nam on to dobronamjerno govori, neka platimo kaznu pa smo mirni. (S. M.)

Znam da izlazi ususret roditeljima koji se boje cijepiti, ne prijavljuje nikoga i ne pravi probleme, a kad god dođem, vidim da je jako zabrinuta. Rekla nam je da su kontrole sve češće i da je u strahu od otkaza. Jednom je pričala kako bi voljela nekako objelodaniti situaciju u svojoj ambulanti u vezi zdravlja cijepljene i necijepljene djece, ali da takvu slobodu najvjerojatnije neće doživjeti. Nisam bila sigurna na što je točno mislila, ali zvučalo je zastrašujuće. (T. Ć.)

Koliko god se o ovakvim iskustvima u javnom prostoru šutjelo, koliko god se obezvrjeđivalo i ponižavalo one koji o tim iskustvima progovaraju, riječ je ipak o vrlo ozbiljnom problemu u kojem je nepovjerenje u sustav cijepljenja rašireno ne samo među zabrinutim i prestrašenim roditeljima nego i među medicinskim stručnjacima. Znanja (službena i popularna ili čak iskustvena) nisu nužno nepovezana niti su univerzalna. Ako se kritičari cjepiva čak i proglase samo teoretičarima zavjera, treba imati na umu da se teorije zavjera mogu čitati samo "u odnosu na dominantni diskurs odnosno ‘službena’ ili ‘legitimna' znanja” (Marković 2018: 266). Sva spomenuta znanja neizbježno su proizvod društvenih odnosa te stoga nisu i ne mogu biti fiksna, podliježu promjenama.

Richard Horton, glavni urednik Lanceta (The Lancet), jednog od najstarijih i najprestižnijih medicinskih znanstvenih časopisa napominje da snaga znanosti leži u njezinoj izvornoj poziciji da nikada ne možemo u potpunosti biti sigurni, da teorije i interpretacije moraju biti podložne i otvorene revizijama u cilju novih i boljih dokaza (Horton 2017). Pritom, posebno je zabrinjavajuća njegova izjava koja se tiče biomedicinske znanosti a kojom iznosi sumnju da "većina znanstvene literature, možda polovica, jednostavno nije istinita. Zahvaćena studijama malobrojnih uzoraka, zanemarivih učinaka, neispravnih istraživačkih analiza i sramnih konflikata interesa" (Horton 2015: 1380).

Službena medicina, koja je u javnosti prihvaćena kao objektivna i neovisna o politici, a njezine ideje podupiru državni aparati i državna vlast, uspješno izbjegava, ali i sprječava 
polemike i kritičku refleksiju. Znanost mora ostati u okvirima svoje temeljne definicije, a to je ne samo dozvoljavanje nego i poticanje kritičkog promišljanja te uvažavanje i razmatranje različitih mišljenja, ali i različitih iskustava. Iskustva, doživljaji i opservacije roditelja nisu i ne mogu biti u istoj ravni sa znanstvenim dokazima premda su roditeljska zapažanja često ključna u brojnim kliničkim istraživanjima. ${ }^{55}$

Poseban potencijal vidim $u$ društvenim i humanističkim znanostima poput etnologije i kulturne etnologije, čijim sam se metodama istraživanja služila, upravo u bilježenju i analizi stavova, iskustava i strahova kao dijela kompletn(ij)e slike. S osloncem "na svjetsku literaturu iz područja medicinske antropologije iz 1980-ih i 1990-ih godina kad su posebno aktualni bili pisanje o potrebi približavanja biomedicine kulturnoj antropologiji i kritika biomedicinskog modela liječenja", u cilju humanijeg liječenja, Jasna Čapo raspravlja o korisnosti i humanosti izgrađivanja odnosa između oboljelih i liječnika koji bi osim biomedicinskih saznanja, uključivao i uvažavanje priča, interpretacija i doživljaja bolesti pacijenta, odnosno u ovom slučaju priče, strahove i doživljaje roditelja djece. "Taj moralni zahtjev nadilazi medicinsku pragmu (korisnost i efikasnost) i ulazi u etičko područje odnošenja prema drugom ljudskom biću" (Čapo 2017: 223-224). Osim poticanja humanijeg odnosa, potencijalna uloga antropologije kao znanstvene discipline koja je "jedinstvena znanost u svom prihvaćanju osobnog iskustva i iskustvenog znanja istraživača kao legitimnog načina produkcije znanja" (Bukovčan 2008: 74), u osiguravanju je prostora "utišavanima”, posebno nakon uviđanja tijekom ovog istraživanja da je jedna strana u znatno nepovoljnijem položaju, degradirana i ismijavana, a legitimna. Upravo nezavidna pozicija i dominantan strah mojih ispitanika da će biti stigmatizirani ukoliko kritički progovaraju o cijepljenju ili javno progovaraju o propustima sustava procjepljivanja navela me, slično kao i Tanju Bukovčan, na "razmišljanje kako neki oblik zagovaranja mora postojati iza svake antropološke priče" (isto) pa su antropološkim metodama istraživanja pojačani glasovi onih koje se ne želi čuti.

Pozivanje na povjerenje $u$ medicinsku struku isključivo argumentom autoriteta, $u$ vrijeme kada se do informacija dolazi lakše nego ikada, kao i prozivanje onih koji traže (zakonom propisane iako ne i osigurane) informacije navodno needuciranim i primitivnim teoretičarima zavjera temeljem njegovanih pretpostavki i predrasuda ne dovodi do bolje komunikacije kojoj se načelno teži niti vodi iznalaženju optimalnog rješenja. Na transparentnost informacija nitko ne bi trebao posjedovati monopol, a ideja da se riskantan, a tek preventivni medicinski postupak ne smije propitivati je vrlo loša ideja, s potencijalno pogubnim posljedicama za javno zdravlje. Također, ona nimalo ne doprinosi većoj procijepljenosti niti povjerenju u sustav. Upravo se propitivanjem sigurnosti cjepiva (u skladu sa zakonima), koje se prikazuje nazadnim, iracionalnim i neznanstvenim, želi osigurati (i sačuvati) sigurnost i zdravlje djece. Osiguravanje informacija značilo bi ostvarivanje zakonom propisanih prava, ali i nadalje ne bi dokinulo sferu straha niti bi riješilo problem načina i politike procjepljivanja djece. Nadležnima za rješavanje tog problema predstoji suočavanje i s nekima od ovdje iznesenih nedoumica i strahova.

${ }^{55}$ Kada se, primjerice, tijekom kliničkih istraživanja promatraju dvije skupine djece, pokusna i kontrolna, upravo roditelji bilježe svoja zapažanja promjena zdravstvenog stanja djeteta nakon cijepljenja. 


\section{NAVEDENA LITERATURA I IZVORI}

Barković, Neven. 2018. "Što je sljedeće? Otvoreno o ravnoj Zemlji?". Indeks. Dostupno na: http://www. index.hr/vijesti/clanak/sto-je-sljedece-otvoreno-o-ravnoj-zemlji/1018689.aspx.

Bešker, Inoslav. 2017. "Kome doista može koristiti huškanje na strah od cjepiva?" Dostupno na: https:// www.jutarnji.hr/komentari/kome-doista-moze-koristiti-huskanje-na-strah-od-cjepiva/5901192/.

Birchall, Clare. 2006. Knowledge Goes Pop. From Conspiracy Theory to Gossip. Oxford, New York: Berg. https://doi.org/10.26530/OAPEN_390769

Borić, Tamara. 2018. "Zbog Kujundžića liječnici nisu prijavili nuspojave cjepiva”. Nacional (31. 5.): 48-51.

Bralić, Irena. 2016. “Cijepljenje. Najuspješniji preventivni program”. Paediatr Croat 60 (Supl 1): 152-159.

Bradaric, Branimir. 2015. "Pobijedila na sudu. Nisam dopustila da cijepe moje tek rođeno dijete". Sloboda.hr. Dostupno na: http://www.sloboda.hr/pobijedila-na-sudu-nisam-dopustila-da-cijepe-moje-tek-rodeno-dijete/.

Bukovčan, Tanja. 2008. "Želim odabrati koga ću voljeti i kamo ići na liječenje'. Aktivizam u istraživanju komplementarne i alternativne medicine u Hrvatskoj". Etnološka istraživanja 12/13: 63-76.

(CDC) Centers for Disease Control and Prevention. Parent's Guide to Childhood immunizations. Dostupno na: https://www.cdc.gov/vaccines/parents/tools/parents-guide/downloads/parents-guide-508.pdf (pristup 1. 5. 2018.).

(CDC) Centers for Disease Control and Prevention. Vaccines and Immunizations. Dostupno na: https:// www.cdc.gov/vaccines/vac-gen/side-effects.htm (pristup 1. 5. 2018.).

Cijepljenje - pravo izbora. Dostupno na: https://www.facebook.com/pravoizbora/.

Čapo, Jasna. 2017. "Integriranje kulturne antropologije u kliničku praksu. Kulturna značenja i odnos liječnika i pacijenta". Etnološka tribina 40/47: 222-235. https://doi.org/10.15378/1848-9540.2017.40.09

Černič, Mateja. 2014. Ideološki konstrukti o cepljenju. Ljubljana: Založba Vega.

Dežulović, Boris. 2017. “Gdje si bio 1791?”. Novosti. Dostupno na: https://www.portalnovosti.com/gdjesi-bio-1791.

Domaradzki, Jan. 2015. "Patient Rights, Risk, and Responsibilities in the Genetic Era. A Right to Know, a Right Not to Know, or a Duty to Know?". Annals of Agricultural and Environmental Medicine 12/1: 156-162. https://doi.org/10.5604/12321966.1141387

Domaradzki, Jan. 2013. “Extra Medicinam Nulla Salus. Medicine as a Secular Religion”. Polish Sociological Review 181: 21-38.

Dopisivanje Gajski HALMED. 2012. SCRIBD. Dostupno na: https://www.scribd.com/document/174424184/ Dopisivanje-Gajski-HALMED-2012.

European Centre for Disease Prevention and Control (ECDC). Vaccine schedules in all countries of the European Union. Dostupno na: https://vaccine-schedule.ecdc.europa.eu/Scheduler/ByCountry?SelectedCountryld=18\&IncludeChildAgeGroup=true\&IncludeChildAgeGroup=false\&IncludeAdultAgeGroup=true\&IncludeAdultAgeGroup=false.

Ethical Codes \& Research Standard. Dostupno na: https://www.hhs.gov/ohrp/international/ethical-codes-and-research-standards/index.html (pristup 10. 4. 2018.).

Fališevac, Josip. 1979. Zarazne bolesti, upoznati-spriječiti-liječiti. Zagreb: Jumena.

Foucault, Michel. 2009. Rađanje klinike. Arheologija medicinskog opažanja. Novi Sad: Mediterran Publishing.

Gastović Bebić, Dorotea. 2016. “Procijepljenost. Kolektivna imunost”. Narodni zdravstveni list 674-675: 15.

HALMED (Agencija za lijekove i medicinske proizvode), Baza lijekova. Dostupno na: http://www.halmed. $\mathrm{hr} /$ Lijekovi/Baza-lijekova/\#rezultati. 
HALMED (Agencija za lijekove i medicinske proizvode), Baza lijekova, Priorix. Dostupno na: http://www. halmed.hr/Lijekovi/Baza-lijekova/Priorix-prasak-i-otapalo-za-otopinu-za-injekciju-u-napunjenoj-strcaljki-cjepivo-protiv-morbila-parotitisa-i-rubele-zivo/12021/.

Horton, Richard. 2015. "Offline. What is Medicine's 5 Sigma?". The Lancet 385: 1380. https://doi. org/10.1016/S0140-6736(15)60696-1

Horton, Richard. 2017. "Offline. Science and the Defeat of Fear". The Lancet 389/10077: 1383. https:// doi.org/10.1016/S0140-6736(17)30934-0

Izvještaj sa Simpozija o cijepljenju. Dostupno na: https://www.hzjz.hr/wp-content/uploads/2015/04/ Izvje\%c5\%a1taj-sa-Simpozija-o-cijepljenju.pdf.

Jergović, Miljenko. 2018. "Cijepljenje ili koga spašavati. Djecu ili dječju paralizu”. Dostupno na: https:// www.jergovic.com/sumnjivo-lice/cijepljenje-ili-koga-spasavati-djecu-ili-djecju-paralizu/ (pristup 12. 11. 2018.).

Kaić, Bernard. 2015. "Broj prijavljenih nuspojava ovisi i o spremnosti zdravstvenih djelatnika da prijave uočenu nuspojavu". Liječničke novine 139: 52-56.

Kaić, Bernard i Vesna Višekruna Vučina. 2016. "Program cijepljenje u Republici Hrvatskoj. Kalendar 'bockanja"'. Narodni zdravstveni list 674-675: 9-12.

Kaic, B, I. Gjenero-Margan, B. Aleraj, T. Vilibić-Čavlek, M. Santak, A. Cvitković, T. Nemeth-Blazic i I. Ivic Hofman. 2010. "Spotlight on Measles 2010. Excretion of Vaccine Strain Measles Virus in Urine and Pharyngeal Secretions of a Child with Vaccine Associated Febrile Rash Illness, Croatia, March 2010". Eurosurveillance 15/35. Dostupno na: https://www.eurosurveillance.org/content/10.2807/ ese.15.35.19652-en.

Kaić, Bernard, Ira Gjenero-Margan i Tatjana Nemeth-Blažić. 2008. “Cijepljenje protiv bolesti uzrokovanih HPV tipovima 6, 11, 16 i 18". Hrvatski časopis za javno zdravstvo 4/13 (7. 1).

Kazneni zakon. Narodne novine 110/1997. Dostupno na: https://narodne-novine.nn.hr/clanci/sluzbeni/1997_10_110_1668.html.

Kleinman, Arthur. 1980. Patients and Healers in the Context of Culture. An Exploration of the Borderland between Anthropology, Medicine, and Psychiatry. Berkeley: University of California Press.

Klokanica (facebook stranica). Dostupno na: https://hr-hr.facebook.com/klokanica.hr/videos/1436656789797281/.

Konvencija o zaštiti ljudskih prava i dostojanstva ljudskih bića glede primjene biologije i medicine: Konvencija o ljudskim pravima i biomedicini. 1998. Vladavina prava 2/3-4: 151-172. Dostupno na: http://www.pravnadatoteka.hr/pdf/aktualno/hrv/20030712/Vladavina_konvencija.pdf.

Kopić, Željka i Valerija Korajac. 2010. “Djeca i djetinjstvo u dokumentima o pravima djece”. Život i škola 24/2, 56: 45-54.

Marjanić, Suzana. 2016. “Teorije zavjera kao urbane predaje/legende s paranoidnom matricom”. Narodna umjetnost 53/2: 111-131.

Marković, Jelena. 2018. "Personal Narrative, Conspiracy Theory and (not) Belonging. Experiences of War, Displacement and Estrangement". Studia ethnologica Croatica 30: 253-277. https://doi. org/10.17234/SEC.30.2

Milas, Josip; Mladen Smoljanović i Maja Miškulin. 2008. "Promjene kalendara cijepljenja. Lobiranje ili struka?". Hrvatski časopis za javno zdravstvo 15/4.

Miller, Neil Z. 2016. “Combining Childhood Vaccinesat One Visit Is Not Safe”. Journal of American Physicians and Surgeons 21/2: 47-49.

MSD priručnik dijagnostike i terapije. Dostupno na: http://www.msd-prirucnici.placebo.hr/msd-prirucnik/klinicka-farmakologija/farmakokinetika. 
Očitovanje Lidije Gajski od 15. listopada 2012. o zahtjevu za pokretanje disciplinskoga postupka. 2012. SCRIBD. Dostupno na: https://www.scribd.com/document/174830787/Gajski-Ocitovanje-disciplinski-15-10-2012.

Pelčić, Gordana. 2016. "Cijepljenje i komunikacija”. medicina fluminensis 52/4: 477-485. https://doi. org/10.21860/medflum2016_4pec

Poljak, Željko. 2011. “Cijepljenje? Da, ali.... Liječničke novine 105: 38-39.

Povelja Europske unije o temeljnim pravima. Dostupno na: http://dubrovnik-europa.eu/uploads/20140123/Povelja\%20Europske\%20unije\%20॰\%20temeljnim\%20pravima.pdf.

Pravilnik o farmakovigilanciji. Narodne novine 83/2013. Dostupno na: https://narodne-novine.nn.hr/ clanci/sluzbeni/2013_07_83_1797.html.

Program zdravstvene zaštite djece, higijene i pravilne prehrane djece u dječjim vrtićima. Narodne novine 105/2002. Dostupno na: https://narodne-novine.nn.hr/clanci/sluzbeni/2002_09_105_1735.html.

Prout, Alan. 2005. The Future of Childhood. Towards the Interdisciplinary Study of Children. London, New York: RoutledgeFalmer, Taylor and Francis Group.

Riksdagen röstade Nej till alla vaccinmotioner. 2017. Dostupno na: http://www.thenhf.se/riksdagen-rostade-nej-till-alla-vaccinmotioner/ (pristup 14. 4. 2018.).

Robin, Corey. 2004. Fear. The History of a Political Idea. Oxford, New York: Oxford University Press.

Salecl, Renata. 2012. Tiranija izbora. Fraktura.

s. n. 2018. "Skandalozno Otvoreno. 'Kako znamo da cijepljenje ne uzrokuje epidemije?"'. Indeks.hr. Dostupno na: https://www.index.hr/vijesti/clanak/skandalozno-otvoreno-kako-znamo-da-cijepljenje-ne-uzrokuje-epidemije/1018663.aspx.

s. n. 2017. "Tešović. Liječnici vjeruju u učinkovitost, neškodljivost i beneficije cijepljenja”. Dostupno na: http://vijesti.hrt.hr/382830/u-splitu-i-rijeci-prosvjedi-protivnika-obveznog-cijepljena.

s. n. 2016. “Majka petogodišnjaka odlučna. 'Nikada više neću cijepiti sina!'; stručnjaci upozoravaju da je to loša odluka". Dostupno na: http://www.sibenik.in/sibenik/majka-petogodisnjaka-odlucna-nikada-vise-necu-cijepiti-sina!-strucnjaci-upozoravaju-da-je-to-losa-odluka/68141.html.

s. n. 2014. "Pravobraniteljica Ivana Milas Klarić zalaže se za obvezno cijepljenje djece". Dostupno na: http://www.in-portal.hr/in-portal-news/vijesti/4652/pravobraniteljica-ivana-milas-klaric-zalaze-se-za-obvezno-cijepljenje-djece.

Srdoč, Silavana. 2017. "Prvi epidemiolog Hrvatske raskrinkava pet mitova protivnika cijepljenja". tportal.hr. Dostupno na: https://www.tportal.hr/vijesti/clanak/prvi-epidemiolog-hrvatske-raskrinkava-pet-mitova-protivnika-cijepljenja-20170425.

Svendsen, Lars Fr. H. 2010. Strah. Zagreb: TIM Press.

Škaričić, Nataša. 2014. "Politika vakcinacije. Između medicinskog paternalizma i teorija zavjere". Kontrapress. Dostupno na: http://www.kontrapress.com/clanak.php?rub=Dru\%C5\%A1tvo\&url=Politika-vakcinacije-Izmedju-medicinskog-paternalizma-i-teorija-zavjere.

Škaričić, Nataša. 2017a. "Bojno polje. O cjepivima, seljacima i debilima za početnike”. Lupiga. Dostupno na: http://lupiga.com/vijesti/bojno-polje-o-cjepivima-seljacima-i-debilima-za-pocetnike?page $=8 \#$ komentari.

Škaričić, Nataša. 2017b. "Bojno polje. O cjepivima, seljacima i debilima za početnike II". Lupiga Dostupno na: http://lupiga.com/vijesti/bojno-polje-o-cjepivima-seljacima-i-debilima-za-pocetnike?page $=8 \#$ komentari.

The National Childhood Vaccine Injury Act of 1986, na National Vaccine Information Center. Dostupno na: https://www.nvic.org/injury-compensation/origihanlaw.aspx. 
Tomić, Ante. 2017. "Ima roditelja koji su totalni idioti, ali to nikad ne shvate. Čak ni kad naprave sranje". Slobodna Dalmacija. Dostupno na: https://www.slobodnadalmacija.hr/misljenja/vlaska-posla/clanak/id/481200/ante-tomic-ima-roditelja-koji-su-totalni-idioti-ali-to-nikad-ne-shvate-cak-ni-kadnaprave-sranje.

Tomić, Ante. 2018. "Epidemija ospica nije sasvim loša ako nakon svega u Saboru više ne bude Živog zida". Slobodna Dalmacija. Dostupno na: https://www.slobodnadalmacija.hr/misljenja/vlaska-posla/clanak/id/524573/ante-tomic-epidemija-ospica-nije-sasvim-losa-ako-nakon-svega-u-saboru-vise-ne-bude-zivog-zida.

Valentine, Gill. 2010. "Children's Bodies. An Absent Presence". U Contested Bodies of Childhood and Youth. Kathrin Hörschelmann i Rachel Colls, ur. Basingstoke: Palgrave Macmillan, 22-37. https:// doi.org/10.1057/9780230274747_2

Vietri, Jeffery T., Meng Li, Alison P. Galvani i Gretchen B. Chapman. 2012. "Vaccinating to Help Ourselves and Others". Medical Decision Making (svibanj-lipanj): 447-458. https://doi.org/10.1177/0272989X11427762

Vlašić, Tatjana. 2018. “Imamo jedno pitanje; kako ovaj gospodin koji tvrdi da je cijepljenje užas još radi kao doktor opće prakse u Dubrovniku?". Telegram. Dostupno na: https://www.telegram.hr/politika-kriminal/imamo-jedno-pitanje-zasto-ovaj-gospodin-koji-zagovara-necijepljenje-jos-radi-kao-doktor-opce-prakse-u-dubrovniku/.

Wolfe, R. M. i L. K. Sharp. 2002. "Anti-vaccinationists Past and Present". BMJ: British Medical Journal 325(7361): 430-432. https://doi.org/10.1136/bmj.325.7361.430

Zakon o lijekovima. Narodne novine 76/2013. Dostupno na: https://narodne-novine.nn.hr/clanci/sluzbeni/2013_06_76_1522.html.

Zakon o zaštiti prava pacijenata. Narodne novine 169/04, 37/08. Dostupno na: https://www.zakon. $\mathrm{hr} / \mathrm{z} / 255 /$ Zakon-o-za\%C5\%A1titi-prava-pacijenata.

Zakon o zaštiti pučanstva od zaraznih bolesti. Narodne novine 79/2007. Dostupno na: https://narodne-novine.nn.hr/clanci/sluzbeni/2007_07_79_2486.html.

Zakon o zdravstvenoj zaštiti. Narodne novine 150/2008. Dostupno na: https://narodne-novine.nn.hr/ clanci/sluzbeni/2008_12_150_4097.html.

Zenić, Divna. 2004. “Pedijatri ‘uvaljuju’ nepotrebno cjepivo”. Slobodna Dalmacija (20. 1).

\section{FEAR AND DECISIONS ABOUT CHILDREN'S HEALTH}

One of the most topical issues in Croatia over the last several years has been to question the (mandatory) vaccination of children. Information on child vaccination being necessary and/or (un)justified was released to the public using various channels and from various standpoints, often only fragmentarily, which resulted in the ideas about vaccination being largely related to various prejudices and preconceptions, leading to a polarization of the opposing sides. Contradictory opinions and attitudes generated opposing positions of those who advocate mandatory vaccination, and those who oppose it. Both sides feel threatened and scared for a variety of reasons; but what is common to both sides is fear (of consequences of vaccination or lack thereof) as well as concern for child health. The present analysis focuses on the images, fears and controversial points articulated in the public space and the production and perception of (in)formal knowledge. The paper centers on 
a heterogenous group of vaccination critics who, in addition to upsetting the dominant discourse, have various fears which are a result of doubts, distrust, (lack of) information. By pointing to specific problems and oversights in the system of vaccination, this group calls into question the mandatory preventive procedure. Although the competence to decide and discuss vaccination is primarily given to medical professionals and only in part to legal professionals, the topic is also examined from a different perspective, primarily in its ethical, political and ideological aspects, given that the idea of controversial medical intervention interferes with the such child health and illnesses choices which are related to human rights, freedoms and responsibilities.

Keywords: fear, vaccination, risk, children, health 